\title{
Biogeochemistry of manganese in ferruginous Lake Matano, Indonesia
}

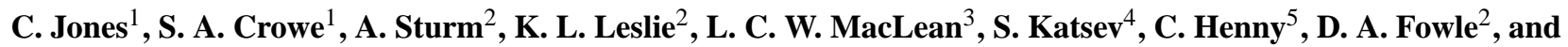 \\ D. E. Canfield ${ }^{1}$ \\ ${ }^{1}$ Nordic Center for Earth Evolution, Institute of Biology, Univ. of Southern Denmark, Campusvej 55, 5230 Odense, Denmark \\ ${ }^{2}$ Dept. of Geology, Univ. of Kansas, Lawrence, KS 66047, USA \\ ${ }^{3}$ Canadian Light Source Inc., Univ. of Saskatchewan, Saskatoon, SK S7N 0X4, Canada \\ ${ }^{4}$ Large Lakes Observatory and Dept. of Physics, Univ. of Minnesota, Duluth MN 55812, USA \\ ${ }^{5}$ Research Center for Limnology, Indonesian Institute of Sciences (LIPI), Cibinong Bogor, Indonesia
}

Received: 26 March 2011 - Published in Biogeosciences Discuss.: 26 April 2011

Revised: 29 September 2011 - Accepted: 4 October 2011 - Published: 26 October 2011

\begin{abstract}
This study explores Mn biogeochemistry in a stratified, ferruginous lake, a modern analogue to ferruginous oceans. Intense Mn cycling occurs in the chemocline where $\mathrm{Mn}$ is recycled at least 15 times before sedimentation. The product of biologically catalyzed Mn oxidation in Lake Matano is birnessite. Although there is evidence for abiotic Mn reduction with $\mathrm{Fe}(\mathrm{II})$, Mn reduction likely occurs through a variety of pathways. The flux of Fe(II) is insufficient to balance the reduction of $\mathrm{Mn}$ at $125 \mathrm{~m}$ depth in the water column, and Mn reduction could be a significant contributor to $\mathrm{CH}_{4}$ oxidation. By combining results from synchrotron-based X-ray fluorescence and X-ray spectroscopy, extractions of sinking particles, and reaction transport modeling, we find the kinetics of Mn reduction in the lake's reducing waters are sufficiently rapid to preclude the deposition of Mn oxides from the water column to the sediments underlying ferruginous water. This has strong implications for the interpretation of the sedimentary Mn record.
\end{abstract}

\section{Introduction}

Relative to its average environmental concentration, $\mathrm{Mn}$ plays a disproportionately large role in the cycling of many biogeochemically relevant compounds in nature, such as organic matter (Sunda and Kieber, 1994), trace metals (Kepkay, 1985; Taillefert et al., 2002; Crowe et al., 2007) and iron

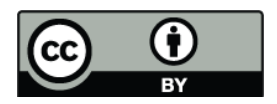

Correspondence to: C. Jones (carriayne@biology.sdu.dk)
(Postma, 1985; Duckworth et al., 2008). In aquatic environments, $\mathrm{Mn}$ is most commonly found in three valence states: reduced $\mathrm{Mn}(\mathrm{II})$, intermediate $\mathrm{Mn}(\mathrm{III})$, and oxidized $\mathrm{Mn}(\mathrm{IV})$. While all three valence states are found in the environment as minerals, only $\mathrm{Mn}$ (II) and complexed $\mathrm{Mn}$ (III) are observed in solution (Canfield et al., 2005). Owing to these multiple oxidation states and the possibility of diffusive transport in its reduced state, manganese is actively cycled by oxidation and reduction reactions in sediments and stratified water columns (Canfield et al., 1993; Murray et al., 1995).

Abiotic manganese oxidation is kinetically limited at circumneutral $\mathrm{pH}$. Under most environmental circumstances, Mn oxidation is a biologically catalyzed process (Tebo et al., 2007), but to date, it has not been conclusively linked to an autotrophic metabolism or cell growth (Canfield et al., 2005). Mn oxidation has long been hypothesized to occur enzymatically via a membrane-bound multicopper oxidase (Brouwers et al., 2000), but recently, a Mn oxidizing heme peroxidase, similar to the one found in fungi, was identified in two Alphaproteobacteria (Anderson et al., 2009). In 2011, it was reported that the Alphaproteobacterium, Roseobacter sp. AzwK- $3 b$ mediates the oxidation of Mn(II) indirectly by enzymatically producing superoxide, which in turn reacts with $\mathrm{Mn}$ (II) (Learman et al., 2011). As of yet, though, the molecular mechanisms underpinning prokaryotic Mn oxidation have not been determined conclusively.

Mn oxide reduction, however, proceeds rapidly through the abiotic oxidation of species such as Fe(II) or sulfide, and Mn oxides can also be reduced biologically, either through fermentative or dissimilatory metabolisms (reviewed in Lovley, 1991). Luther et al. (1997) suggested $\mathrm{NH}_{4}^{+}$as a potential

Published by Copernicus Publications on behalf of the European Geosciences Union. 
reductant for Mn oxides, though a later study found no evidence of this reaction in the environment (Thamdrup and Dalsgaard, 2000). Recent studies, including one at Lake Matano, have linked biological $\mathrm{Mn}$ (and Fe) oxide reduction to methane oxidation (Beal et al., 2009; Crowe et al., 2011). Lake Matano provides some of the most compelling evidence to date of $\mathrm{CH}_{4}$ oxidation coupled to $\mathrm{Fe} / \mathrm{Mn}$ oxide reduction given the dearth of both $\mathrm{SO}_{4}^{2-}$ and $\mathrm{NO}_{3}^{-}$in the lake.

Most studies of manganese redox cycling have focused on sediments (reviewed in Thamdrup, 2000), whereas substantially fewer have looked at chemically stratified water columns (Bratina et al., 1998; Taillefert et al., 2002; Balistrieri et al., 1992; Murray et al., 1995). A conceptual model of $\mathrm{Mn}$ and $\mathrm{O}_{2}$ water column profiles generally applicable to most stratified aquatic environments (e.g. Lake Vanda, the Black Sea, Lake Bret, etc.) (see Davison, 1993 for a review) is shown in Fig. 1. Reactions controlling the oxidation and reduction of $\mathrm{Mn}$ are shown in Table 1. Commonly, Mn oxidation occurs where $\mathrm{Mn}$ (II) and oxygen coexist, with concomitant Mn particle formation. Just below the depth of oxygen penetration, a peak in the dissolved manganese concentration develops from reduction of these particles as they settle. Contrary to the generally accepted cascade of terminal electron acceptors used in stratified environments (Froelich et al., 1979), Mn reduction can occur in oxic environments (Bratina et al., 1998; Canfield et al., 2005), so oxidation and reduction can occur simultaneously in the same water mass. Dissolved Mn concentrations typically decrease with depth in anoxic water (Davison, 1993), potentially through precipitation of a Mn(II)-bearing mineral phase.

Perhaps the best-studied stratified water column with respect to Mn geochemistry is the Black Sea, where N and S may play key roles in Mn cycling. One-dimensional modeling implicated nitrate, as opposed to $\mathrm{O}_{2}$, as an alternative oxidant for Mn in this zone (Murray et al., 1995), but this has yet to be corroborated with field studies (Clement et al., 2009; Schippers et al., 2005).

In Lake Matano, a $590 \mathrm{~m}$ deep meromictic lake located on Sulawesi Island, Indonesia, Mn(II) is mixed into the oxic zone where it is oxidized. The oxides sink below the redox boundary where there is very little sulfide to act as reductant, but there is ample $\mathrm{Fe}(\mathrm{II}), \mathrm{NH}_{4}^{+}$, and $\mathrm{CH}_{4}$. Therefore, Lake Matano offers a contrasting glimpse of manganese biogeochemical cycling in a unique, Fe-rich, S-poor system. Here, we use synchrotron-based X-ray spectroscopy and Xray fluorescence analyses of water column particles, selective chemical extractions of water column particles, lake water incubations, and reaction transport modeling to quantify the oxidation and reduction kinetics of $\mathrm{Mn}$. We then place the results of this work into geobiological context and offer an alternative interpretation for Precambrian sedimentary Mn enrichments.

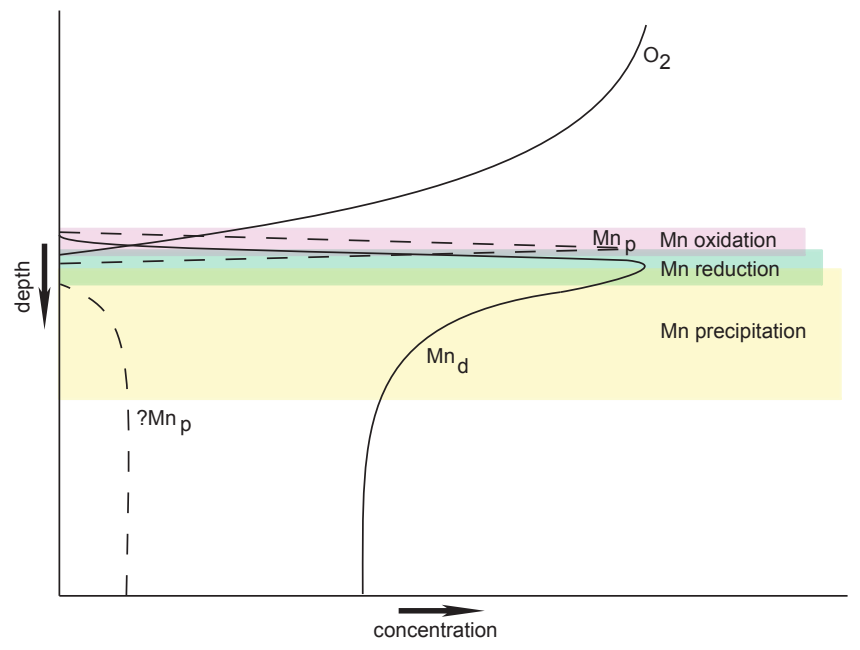

Fig. 1. Conceptualized $\mathrm{Mn}$ (dissolved and particulate) and $\mathrm{O}_{2}$ profiles.

\section{Location}

The Malili Lake system is situated on the southeastern peninsula of Sulawesi Island, Indonesia (Crowe et al., 2008b). The Lake Matano basin $\left(164 \mathrm{~km}^{2}\right)$ is formed by a horst and graben depression, and at nearly $600 \mathrm{~m}$ deep, it is the eighth deepest lake in the world. Between one and four million years in age, it is also one of only a handful of ancient lakes on the planet. It has a catchment made predominantly of ophiolitic rock and weathered lateritic soils (Golightly, 1981), which contribute to the high (40-60\%; Crowe et al., 2004) iron (hydr)oxide concentrations in the lake sediments. The lake is persistently stratified by weak thermal and salinity gradients (Crowe et al., 2008b) that have likely been maintained for centuries (Katsev et al., 2010). Lake Matano has been suggested as the best modern analogue for the Precambrian, ferruginous oceans (Crowe et al., 2008a).

\section{Materials and methods}

\subsection{Sampling}

Sampling was conducted at a central, deep-water station $\left(2^{\circ} 28^{\prime} 00^{\prime \prime} \mathrm{S}\right.$ and $\left.121^{\circ} 17^{\prime} 00^{\prime \prime} \mathrm{E}\right)$ in January-March 2009 . Water samples were collected by one of two methods. In the first, we used 51 Go-Flow (Niskin) bottles attached in series to a stainless steel cable placed at depth with a precision and accuracy of $\pm 1 \mathrm{~m}$ using a commercial sonar device (Furuno FCV585) to monitor the position of the bottles within the water column. In the second method, we collected water with a Johnson WPS 2.9 diaphragm pump through $150 \mathrm{~m}$ of $1 \mathrm{~cm}$ internal diameter plastic tubing. The depth of the pump inlet was set using a conductivity, temperature, depth probe (CTD, Sea and Sun Technology) mounted just above the pump inlet 
Table 1. Reactions controlling Mn cycling in stratified water columns.

\begin{tabular}{ll}
\hline Mn Oxidation Reactions & Mn Reduction reactions \\
\hline $2 \mathrm{Mn}^{2+}+\mathrm{O}_{2}+2 \mathrm{H}_{2} \mathrm{O} \rightarrow 2 \mathrm{MnO}_{2}+4 \mathrm{H}^{+}$ & $2 \mathrm{Fe}^{2+}+\mathrm{MnO}_{2}+2 \mathrm{OH}^{-} \rightarrow 2 \mathrm{FeOOH}+\mathrm{Mn}^{2+}$ \\
$5 \mathrm{Mn}^{2+}+2 \mathrm{NO}_{3}^{-}+4 \mathrm{H}_{2} \mathrm{O} \rightarrow 5 \mathrm{MnO}_{2}+\mathrm{N}_{2}+8 \mathrm{H}^{+\mathrm{a}}$ & $\mathrm{H}_{2} \mathrm{~S}+4 \mathrm{MnO}_{2}+2 \mathrm{H}_{2} \mathrm{O} \rightarrow \mathrm{SO}_{4}^{2-}+4 \mathrm{Mn}^{2+}+6 \mathrm{OH}^{-}$ \\
$2 \mathrm{Mn}^{2+}+\mathrm{HCO}_{3}^{-}+2 \mathrm{H}_{2} \mathrm{O} \rightarrow 2 \mathrm{MnO}_{2}+\mathrm{CH}_{2} \mathrm{O}+3 \mathrm{H}^{+b} \mathrm{CH}$ & $\mathrm{CH}_{3} \mathrm{COO}^{-}+4 \mathrm{MnO}_{2}+3 \mathrm{H}_{2} \mathrm{O} \rightarrow 2 \mathrm{HCO}_{3}^{-}+4 \mathrm{Mn}^{2+}+7 \mathrm{OH}^{-}$ \\
& $3 \mathrm{MnO}_{2}+2 \mathrm{NH}_{4}^{+}+4 \mathrm{H}^{+} \rightarrow 3 \mathrm{Mn}^{2+}+\mathrm{N}_{2}+6 \mathrm{H}_{2} \mathrm{O}^{\mathrm{a}}$ \\
& $4 \mathrm{MnO}_{2}+\mathrm{NH}_{4}^{+}+6 \mathrm{H}^{+} \rightarrow 4 \mathrm{Mn}^{2+}+\mathrm{NO}_{3}^{-}+5 \mathrm{H}_{2} \mathrm{O}^{\mathrm{a}}$ \\
& $\mathrm{CH}_{4}+4 \mathrm{MnO}_{2}+7 \mathrm{H}^{+} \rightarrow \mathrm{HCO}_{3}^{-}+4 \mathrm{Mn}^{2+}+5 \mathrm{H}_{2} \mathrm{O}^{\mathrm{a}}$ \\
\hline
\end{tabular}

Reactions marked with letter "a" have been suggested based on indirect evidence while that marked with letter "b" is only hypothesized.

and interfaced to a computer at the surface using a hydrowire. This set-up allowed real-time positioning of the pump inlet with a vertical accuracy of $0.1 \mathrm{~m}$ and a between-cast precision of $0.25 \mathrm{~m}$. Prior to sampling, the tubing was flushed with at least three times its internal volume (12l) using the diaphragm pump. Following the flushing period, water was pumped for sampling using a peristaltic pump (Masterflex L/S computerized drive, model number 7523-60) through a combination of Tygon ${ }^{\circledR}$ and Marprene ${ }^{\circledR}$ tubing.

Samples for dissolved manganese and major ion concentrations were taken directly from the Niskin bottle spout or pump stream with a syringe and filtered through a $0.2 \mu \mathrm{m}$ pore, $25 \mathrm{~mm}$ diameter cellulose acetate filter into acid washed HDPE $125 \mathrm{ml}$ bottles that were rinsed three times with sample water. Samples were acidified to $2 \%$ with tracemetal grade $\mathrm{HNO}_{3}$. Samples for $\mathrm{Fe}(\mathrm{II})$ were taken directly from the Niskin bottle spout or from the pump stream with a pipette and placed immediately in ferrozine reagent to avoid oxidation. These samples were unfiltered as Fe particles could contribute at most $200 \mathrm{nM}$ to the $\mathrm{Fe}$ (II) determination, and filtration would likely have oxidized some of the Fe(II) (Troup et al., 1974). All $\mathrm{Fe}$ and $\mathrm{Mn}$ samples were refrigerated and maintained at $4{ }^{\circ} \mathrm{C}$ until analysis within $8 \mathrm{~h}$. Surface water particles (collected from 20 and $90 \mathrm{~m}$ depth) were sampled by pumping water and filtering 10-201 through a $0.2 \mu \mathrm{m}$ pore, $142 \mathrm{~mm}$ diameter, polycarbonate filter housed on an in-line (allowing no contact with atmosphere) filtration device. Filters for bulk X-ray absorption near edge structure (XANES) analysis were sealed in Kapton ${ }^{\circledR}$ tape prior to storage. Kapton ${ }^{\circledR}$ is a strong, low molecular weight polyimide that is nearly transparent to hard X-rays $(>4000 \mathrm{eV})$ and resists damage from radiation (Alkire and Rotella, 1997), so it makes an excellent protective sheath for samples to be analyzed by hard X-ray techniques. The filters were stored frozen at $-20^{\circ} \mathrm{C}$ in $50 \mathrm{ml}$ plastic tubes until analysis. Chemocline particle samples were taken in a similar fashion, except they were filtered and handled in a glove bag on board a local fishing boat under an atmosphere of high purity nitrogen. Like surface water particle filters, chemocline particle filters for bulk XANES were sealed in Kapton ${ }^{\circledR}$ tape, which also served as an additional oxygen barrier before storage.
All chemocline particle filters were stored in nitrogen-filled glass vials at $-20^{\circ} \mathrm{C}$ until analysis.

\subsection{Sample analyses}

Dissolved oxygen, temperature, conductivity, and turbidity were measured in situ using a multiparameter probe (Sea and Sun Technology). Mn, Fe, and major ion concentrations were determined on a Perkin Elmer Optima 5300DV ICP-OES. Fe(II) was analyzed by the ferrozine method (Viollier et al., 2000; Stookey, 1970). Chemocline carbon fixation rates were measured in situ at 122, 124, 126, 128, 130, and $135 \mathrm{~m}$ using the $\mathrm{H}^{13} \mathrm{CO}_{3}^{-}$technique (Slawyk et al., 1977) and integrated to attain an area specific rate. Methane and ammonium data are reproduced from Crowe et al. (2011).

\subsection{Mn oxidation rate incubations}

Samples for determining manganese oxidation rates were acquired by pumping water from four depths $(118,119,120$, and $121 \mathrm{~m}$ ) into triplicate, acid cleaned, $60 \mathrm{ml}$ glass vials, first rinsed 3 times with sample water, then crimp sealed with rubber septa. Within $4 \mathrm{~h}$, these samples were amended with a $\mathrm{MnCl}_{2}$ solution to a total $\mathrm{Mn}$ concentration of approximately $40 \mu \mathrm{mol}^{-1}$. Controls from each depth were additionally amended with $100 \mu \mathrm{l}$ of $37 \%$ formaldehyde. Incubations were kept at $28^{\circ} \mathrm{C}$ in the dark and subsampled by injecting an equal volume of sterile-filtered air as the sample was removed $\left(4 \mathrm{~cm}^{3}\right)$. A time-zero sample was taken immediately from each vial. $\mathrm{Mn}$ (II) concentrations were analyzed in duplicate spectrophotometrically by the formaldoxime method (Brewer and Spencer, 1971).

\subsection{Water column particle extractions}

Particulate manganese concentrations were determined from particles collected on $0.2 \mu \mathrm{m}$ pore, $142 \mathrm{~mm}$ diameter, polycarbonate filters. A known fraction of each filter was extracted following the parallel, selective sediment extraction protocols of Neaman et al. (2004). This involved extracting with $0.1 \mathrm{moll}^{-1}$ hydroxylamine $\mathrm{HCl}$ for $2 \mathrm{~h}$ to obtain $\mathrm{Mn}$ oxides, although this extraction also incompletely dissolves the 
Al-Li-Mn oxide, lithiophorite, and could also attack Fe oxides (Neaman et al., 2004). A parallel extraction used $30 \%$ $\mathrm{H}_{2} \mathrm{O}_{2}$ with $0.5 \mathrm{~N} \mathrm{HNO}_{3}$ for $0.5 \mathrm{~h}$. It attacks $\mathrm{Mn}$ and $\mathrm{Fe}$ oxides, and potentially, organic matter (Neaman et al., 2004). In addition to these two parallel extractions, a sequential extraction of $0.5 \mathrm{~N} \mathrm{HCl}$ for $1 \mathrm{~h}$ was followed by digestion in $6 \mathrm{~N} \mathrm{HCl}$ for $24 \mathrm{~h}$ at $100^{\circ} \mathrm{C}$ to obtain reactive $\mathrm{Fe}$ and total extractible Fe and Mn, respectively (Lovley and Phillips, 1986; Poulton and Canfield, 2005). Filter extracts were analyzed on a Perkin Elmer Optima 5300DV ICP-OES for Fe, Mn, and other major ions.

\subsection{Transmission Electron Microscopy (TEM)}

Particles for TEM analyses were collected on $142 \mathrm{~mm}$ diameter polycarbonate filters as described above. Particles were washed from the filter surface with anaerobic deionized water, pipetted onto copper TEM grids, and dried. All manipulations were done in an anaerobic chamber. TEM micrographs were collected on a Tecnai $20 \mathrm{D} 491 \mathrm{X}$-Twin transmission electron microscope. The TEM operates at $200 \mathrm{kV}$ using a field emission gun in STEM nP LM zoom diffraction mode as an electron source and is equipped with an energy dispersive X-ray spectrometer (EDS) operated at $4.2 \mathrm{kV}$ extraction voltage.

\subsection{Synchrotron-based X-Ray fluorescence and spectroscopy}

Particles for synchrotron x-ray spectroscopic analyses were collected and preserved on $142 \mathrm{~mm}$ diameter polycarbonate filters as described above. Micro X-ray Fluorescence ( $\mu$ XRF) maps and (micro) X-ray absorption near edge structure (XANES and $\mu$ XANES) spectra were collected on beamline 20-BM-B (PNC-CAT) at the Advanced Photon Source (APS) at Argonne National Laboratory, Illinois. The filter sample was mounted on a vertical plastic sample holder oriented at $45^{\circ}$ to the beam in the horizontal plane. The incident Xray beam was focused using a pair of Kirkpatrick-Baez mirrors, and a monochromatic incident beam was achieved using a $\mathrm{Si}(111)$ double crystal monochromator. Filters used for $\mu \mathrm{XANES}$ and $\mu \mathrm{XRF}$ analyses were subsampled, and a single piece was placed particle-side down on kapton film then sealed in kapton tape under a nitrogen atmosphere prior to spectra collection.

$\mu \mathrm{XRF}$ elemental maps were collected with monochromatic incident X-rays $(\mathrm{Si}(111))$ tuned to $14000 \mathrm{eV}(\lambda=$ $0.5580 \AA$ ) and focused to a spot size of $5 \mu \mathrm{m}$ by $5 \mu \mathrm{m}$ using a pair of Kirkpatrick-Baez mirrors. The sample was rastered through the X-ray beam in $5 \mu \mathrm{m}$ steps with a count time of $1 \mathrm{~s}$ per step. The emitted fluorescence X-rays of 9 elements (Ti $K \alpha$, V $K \alpha$, Cr $K \alpha, \operatorname{Mn} K \alpha$, Fe $K \alpha$, Co $K \alpha$, Ni $K \alpha, \mathrm{Cu}$ $K \alpha$, and $\mathrm{Zn} K \alpha$ ) were collected simultaneously with a 13element Germanium detector (Canberra). In $\mu$ XRF mapping, $\mathrm{Fe}$ and $\mathrm{Mn}$ raw intensity counts were calibrated to moles by integrating the raw intensity counts, less the average blank, in a given area and dividing by the concentration of $\mathrm{Fe}$ or $\mathrm{Mn}$ per given filter area as determined by total extractions.

$\mu X A N E S$ spectra were collected in fluorescence mode on selected areas of the $\mu$ XRF map where Mn counts were high. The $\mathrm{Si}(111)$ monochromator was calibrated to the $\mathrm{Mn} \mathrm{K} \alpha$ edge at $6539 \mathrm{eV}$ using the first peak of the first derivative XANES spectrum for the Mn metallic foil. The energy scale for each sample was referenced to the edge in the Mn foil spectrum collected in transmission mode simultaneously with sample data. The X-ray absorption structure (XAS) data were normalized and processed using Athena 8.054 (Ravel and Newville, 2005).

\section{Results and discussion}

\subsection{Limnological features}

Lake Matano is a deep, steep-sided, tropical lake that maintains a persistent pycnocline near $100 \mathrm{~m}$ depth. This stratification is largely due to weak thermal and salinity gradients that persist because of the lake bathymetry and the lack of large seasonal temperature fluctuations in the tropics (Crowe et al., 2008b; Katsev et al., 2010). Figure 2 shows temperature and density profiles from 2004 to 2010 . These profiles depict seasonal, surface water differences but highlight the stability of the $\sim 100 \mathrm{~m}$ deep, persistent pycnocline. In 2009 , however, the depth of the oxic mixed layer was $\sim 10 \mathrm{~m}$ deeper than previous years for reasons that remain unknown. In 2010, the depth of the oxic mixed layer shallowed to near its pre-2009 position. When discussing concentration profiles, we will refer to the depths and concentrations measured in 2009, unless otherwise stated, as most of our analyses and incubations were done this year.

The chemical structure of the Lake Matano water column has been previously described (Crowe et al., 2008b), and in general, our observations are consistent with this earlier work (Fig. 3). The dissolved Mn(II) concentration profile develops as a balance between sources and sinks, where Mn(II) oxidation is a sink, $\mathrm{Mn}(\mathrm{III} / \mathrm{IV})$ reduction is a source, and precipitation of a Mn-bearing mineral is a sink. As it is currently understood, Mn oxidation requires molecular oxygen despite previous suggestions that $\mathrm{NO}_{3}^{-}$could act as an oxidant (see Luther et al., 1997; Murray et al., 1995; Schippers et al., 2005; Clement et al., 2009 for a discussion). In Lake Matano, oxygen concentration gradients reflect the physical structure of the water column and oxygen demands. In the surface water, oxygen concentrations are near atmospheric saturation and decline due to respiration with increasing depth as the persistent pycnocline is approached (Fig. 3). Oxygen becomes undetectable with our methods at $120 \mathrm{~m}( \pm 3 \mathrm{~m}$ between casts, conservatively, due to seiching/internal waves; Katsev et al., 2010). The steep oxygen, $\mathrm{Mn}$, and Fe gradients define a chemocline, and the point of undetectable oxygen 

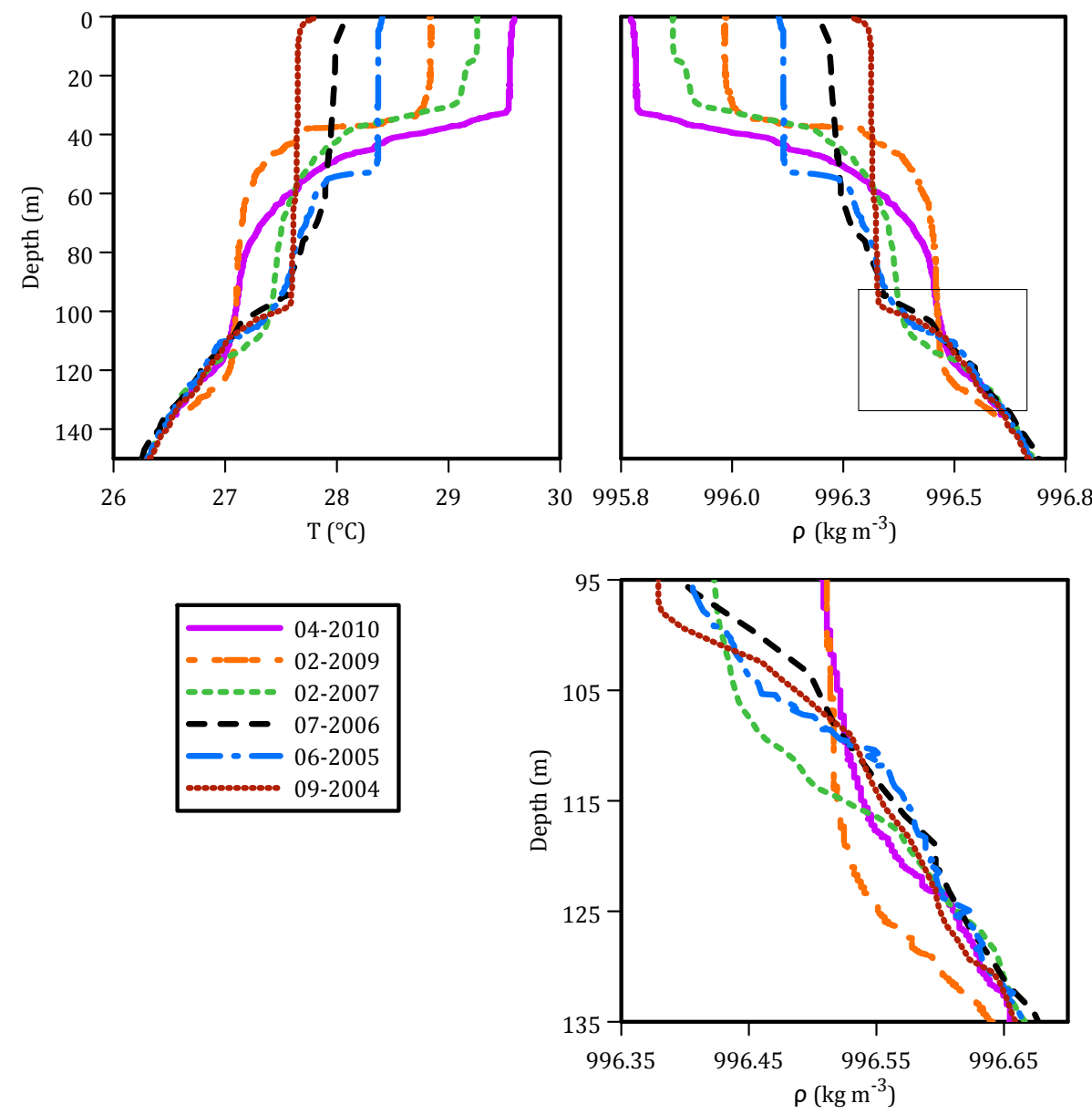

Fig. 2. Seasonal temperature and density in Lake Matano from 2004 to 2010.

defines a redox boundary that separates aerobic from anaerobic processes. We will reference other chemical species and processes to these features. As conceptualized in Fig. 1 and depicted for the specific case of Lake Matano in Fig. 3, dissolved manganese concentrations are sub-micromolar in the surface waters and high $\left(\sim 6 \mu \mathrm{mol}{ }^{-1}\right)$ in the bottom waters with a peak in concentration of $\sim 17 \mu \mathrm{moll}^{-1}$ below the redox boundary, near $125 \mathrm{~m}$. Particulate $\mathrm{Mn}$ and Fe accumulate to concentrations of 360 and $170 \mathrm{nmoll}^{-1}$, respectively, at $118.6 \mathrm{~m}$.

\subsection{Mn oxidation and reduction: evidence from water column particles}

Particles collected from the upper $130 \mathrm{~m}$ of the water column were analyzed by selective and total extractions (Table 2), XAS, and $\mu$ XRF (Figs. 4, 5, and 6). A TEM micrograph of particles from $118.6 \mathrm{~m}$ is presented in Fig. 7. The TEM image shows aggregates of dark, fibrous minerals, similar in morphology to Mn oxides studied previously (Cheney et al., 2008). Also in the figure, EDS elemental spectra confirms that these dark fibrous particles are predominately $\mathrm{Mn}$ and $\mathrm{O}$.
In general, particulate Mn concentrations as determined by our extraction methods reached a maximum at $118.6 \mathrm{~m}$. Extraction of particles in $6 \mathrm{~N} \mathrm{HCl}$ (Table 2) demonstrates a sharp particulate $\mathrm{Mn}$ concentration peak with very little $\mathrm{Mn}$ in particles below $118.6 \mathrm{~m}$ or in the surface water. Fe particles show a peak above background levels at $118.6 \mathrm{~m}$ as well, but higher concentrations are sustained to deeper depths suggesting the persistence of authigenic Fe phases to depth in the lake. To summarize, while both $\mathrm{Mn}$ and $\mathrm{Fe}$ particles peak at $118.6 \mathrm{~m}$, authigenic $\mathrm{Fe}$ particles persist deeper than $\mathrm{Mn}$ particles. There could be several reasons for this observation: sinking Mn oxides produced during Mn oxidation may be generating the $\mathrm{Fe}$ oxides by oxidizing $\mathrm{Fe}$ (II) diffusing up from below. This would produce a profile with a Mn oxide peak just above an $\mathrm{Fe}$ oxide peak, which may not be discernable at the resolution of our sampling. In addition, $\mathrm{Mn}$ oxides are more easily reduced than Fe oxides (Krauskopf, 1957; Crowe et al., 2007), so Fe particles may be sustained deeper than Mn particles due to their relatively lower reactivity. 

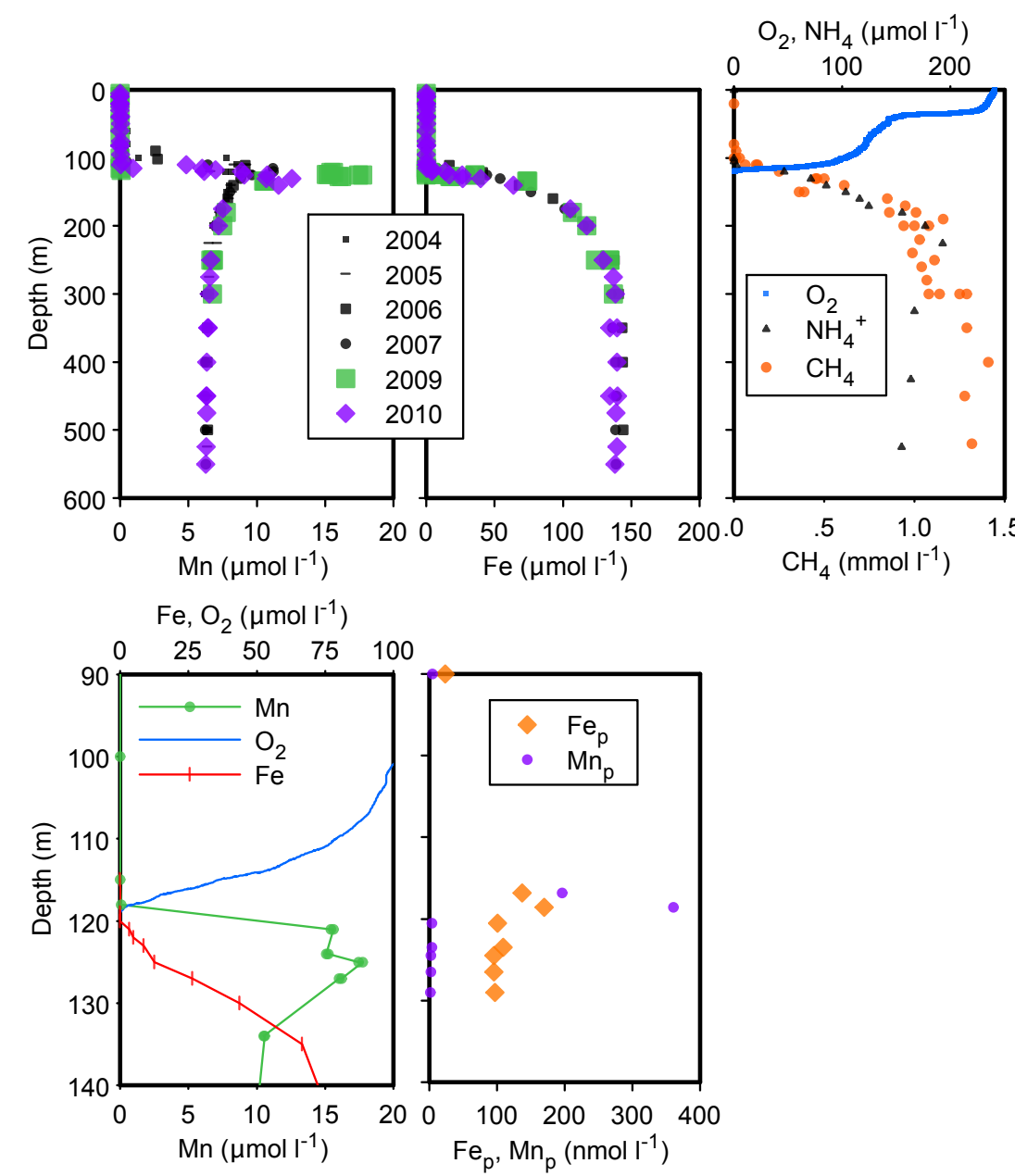

Fig. 3. Lake Matano water column profile of dissolved Mn (left panel) and dissolved Fe (middle panel) from 2004 to 2010 . Right panel shows representative dissolved $\mathrm{O}_{2}, \mathrm{NH}_{4}^{+}$, and $\mathrm{CH}_{4}$ profiles. $\mathrm{CH}_{4}$ and $\mathrm{NH}_{4}^{+}$profiles are reproduced from Crowe et al. (2011). Bottom panels are a closer view of the chemocline with the left panel displaying $\mathrm{O}_{2}$, dissolved $\mathrm{Mn}(\mathrm{II})$, and $\mathrm{Fe}(\mathrm{II})$, while the bottom right panel shows particulate $\mathrm{Fe}$ and $\mathrm{Mn}$.

Water column particles were extracted with two different methods; one uses acidified $\mathrm{H}_{2} \mathrm{O}_{2}$ and one uses hydroxylamine $\mathrm{HCl}$ (Neaman et al., 2004). These extractions should allow the discrimination of pure Mn oxides (e.g. birnessite, pyrolusite, $\partial \mathrm{MnO}_{2}$ ) from $\mathrm{Mn}$ contained in $\mathrm{Fe}$ oxides, as well as Al-containing Mn minerals like lithiophorite, which, together with Mn oxides, are common in the lateritic catchment soils of Lake Matano (Golightly, 1981). However, the acidified $\mathrm{H}_{2} \mathrm{O}_{2}$ extraction appears to have digested the $\mathrm{Fe}$ oxides as well as $\mathrm{Mn}$ oxides, since both the $\mathrm{H}_{2} \mathrm{O}_{2}$ and hydroxylamine $\mathrm{HCl}$ extraction yielded the same amount of Fe. Both of the extractions also dissolved approximately the same amount of Mn (Table 2), suggesting that lithiophorite, despite being a component of the catchment soils, is not common in the water column. These results verify that Mn oxides are the dominant Mn-bearing phase in the chemocline.
At $118.6 \mathrm{~m}$, a large fraction of the total extractable $\mathrm{Mn}$ is only extracted by sub-boiling $6 \mathrm{~N} \mathrm{HCl}$. This suggests the formation of a Mn species that is not reactive to the selective extractions described above. This Mn species, however, like other oxidized forms of $\mathrm{Mn}$, is subsequently dissolved by reduction as it sinks through the water column (see below). Additionally, the $0.5 \mathrm{M} \mathrm{HCl}$ extraction failed to extract most of the particulate $\mathrm{Fe}$ in the surface and deep waters. This suggests that a large fraction of the Fe particles raining through the water column is relatively unreactive.

The average oxidation state of the particles at four depths $(20,118.6,123.5$, and $129 \mathrm{~m})$ was determined by bulk Mn XANES spectra, and the results are shown in Fig. 4. In the surface water sample where particulate $\mathrm{Mn}$ is present at concentrations much less than at $118.6 \mathrm{~m}$, the oxidation state is predominantly $\mathrm{Mn}(\mathrm{II})$. Surface waters are extremely clear, with secchi depths greater than $23 \mathrm{~m}$, and particles at these 
Table 2. Selective and total extractions of Fe and $\mathrm{Mn}$ in water column particles.

\begin{tabular}{|c|c|c|c|c|c|}
\hline & $\left(\mathrm{nmol}^{-1}\right)$ & $\begin{array}{r}\mathrm{H}_{2} \mathrm{O}_{2}+ \\
0.5 \mathrm{~N} \mathrm{HNO}_{3}\end{array}$ & $\begin{array}{r}\mathrm{NH}_{2} \mathrm{OH}- \\
\mathrm{HCl}\end{array}$ & $\begin{array}{r}0.5 \mathrm{~N} \\
\mathrm{HCl}\end{array}$ & Total \\
\hline \multirow[t]{2}{*}{$20 \mathrm{~m}$} & $\mathrm{Fe}$ & 2 & 1 & 2 & 77 \\
\hline & $\mathrm{Mn}$ & 1 & 1 & 1 & 3 \\
\hline \multirow[t]{2}{*}{$90 \mathrm{~m}$} & $\mathrm{Fe}$ & 4 & 1 & 4 & 24 \\
\hline & $\mathrm{Mn}$ & 1 & 1 & 1 & 3 \\
\hline \multirow[t]{2}{*}{$116.5 \mathrm{~m}$} & $\mathrm{Fe}$ & 29 & 7 & 27 & 107 \\
\hline & $\mathrm{Mn}$ & 44 & 47 & 13 & 148 \\
\hline \multirow[t]{2}{*}{$118.6 \mathrm{~m}$} & $\mathrm{Fe}$ & 33 & 6 & 35 & 170 \\
\hline & $\mathrm{Mn}$ & 77 & 79 & 28 & 361 \\
\hline \multirow[t]{2}{*}{$120.5 \mathrm{~m}$} & $\mathrm{Fe}$ & 21 & 10 & 21 & 101 \\
\hline & $\mathrm{Mn}$ & 1 & 1 & 1 & 3 \\
\hline \multirow{2}{*}{$123.5 \mathrm{~m}$} & $\mathrm{Fe}$ & 13 & 2 & 15 & 109 \\
\hline & $\mathrm{Mn}$ & 1 & 1 & 1 & 3 \\
\hline \multirow[t]{2}{*}{$124.5 \mathrm{~m}$} & $\mathrm{Fe}$ & 14 & 4 & 14 & 95 \\
\hline & $\mathrm{Mn}$ & 1 & 0 & 1 & 2 \\
\hline \multirow[t]{2}{*}{$126.5 \mathrm{~m}$} & $\mathrm{Fe}$ & 26 & 10 & 24 & 96 \\
\hline & $\mathrm{Mn}$ & 1 & 1 & 1 & 2 \\
\hline \multirow[t]{2}{*}{$129 \mathrm{~m}$} & $\mathrm{Fe}$ & 26 & 9 & 29 & 97 \\
\hline & $\mathrm{Mn}$ & 1 & 0 & 1 & 1 \\
\hline
\end{tabular}

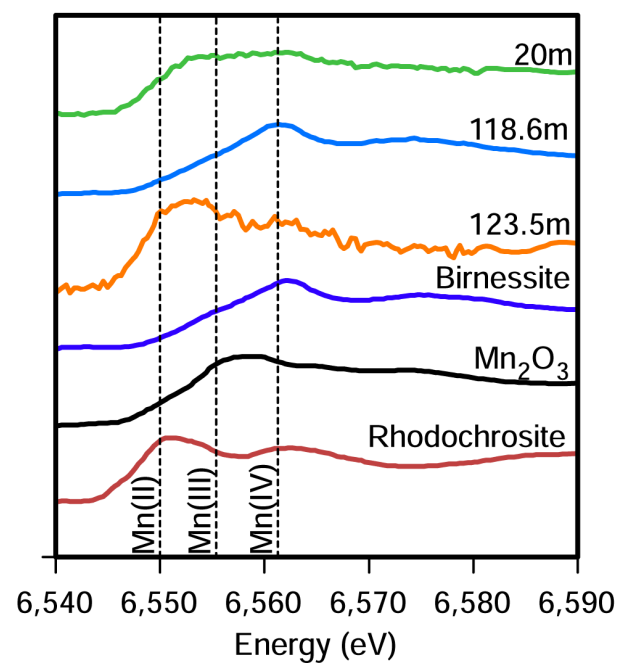

Fig. 4. Bulk XANES spectra of standards and water column particles. $\mathrm{Mn}_{2} \mathrm{O}_{3}$ spectra courtesy of Steve Heald at Argonne National Laboratory.

depths are mostly cellular material. The observed Mn(II) may, therefore, be incorporated into bacterial enzymes and oxygen-evolving complexes of oxygenic phototrophs, although $\mathrm{Mn}$ (II) incorporated into silicates cannot be ruled out, as the $6 \mathrm{~N} \mathrm{HCl}$ extraction would not completely digest silicate

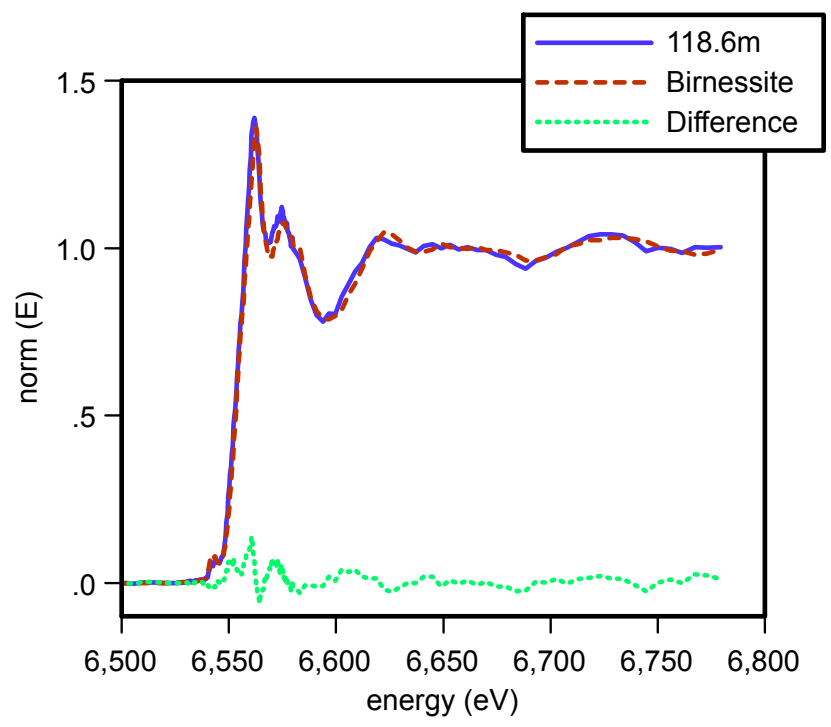

Fig. 5. Averaged XAS spectra from $118.6 \mathrm{~m}$ water column particles, XAS spectrum of synthesized birnessite, and the residual spectrum from subtracting these two spectra.

minerals. In contrast, the oxidation state of $\mathrm{Mn}$ in particles at $118.6 \mathrm{~m}$ is predominantly $\mathrm{Mn}(\mathrm{IV})$. We find no evidence for a significant $\mathrm{Mn}$ (II) contribution, implying that sorption to particles is not a major sink for $\mathrm{Mn}$ (II) in this environment.

To identify the mineralogy of these Mn(IV) particles, the bulk XAS spectrum from $118.6 \mathrm{~m}$ has been plotted along with the spectrum of a birnessite standard (Fig. 5), and these two spectra are nearly identical. The dominant Mn mineralogy at $118.6 \mathrm{~m}$ appears, therefore, to be birnessite, consistent with previous studies of biological Mn oxidation products in lake environments, as well as in marine and laboratory culture studies (e.g. Friedl et al., 1997; Dick et al., 2009; Villalobos et al., 2003). By $123.5 \mathrm{~m}$, the bulk XANES spectrum suggests that particulate $\mathrm{Mn}$ is predominantly $\mathrm{Mn}(\mathrm{II})$, and as mentioned above, particulate $\mathrm{Mn}$ concentrations are much lower than at $118.6 \mathrm{~m}$. The particulate $\mathrm{Mn}$ at $123.5 \mathrm{~m}$ may represent cellular $\mathrm{Mn}(\mathrm{II}), \mathrm{Mn}$ (II) adsorbed onto Fe oxides or other water column particles, or Mn(II) minerals like pseudo kutnahorite or rhodochrosite. At $129 \mathrm{~m}$, no particulate $\mathrm{Mn}$ was detectable by bulk XANES.

In Fig. 6, $\mu$ XRF maps of particles from the same four depths are shown. These maps illustrate the spatial distribution of $\mathrm{Fe}$ and $\mathrm{Mn}$ on the filters at the micrometer scale. As noted above, concentrations of both $\mathrm{Mn}$ and $\mathrm{Fe}$ in particles increase at $118.6 \mathrm{~m}$. $\mu$ XRF maps show considerable spatial association between $\mathrm{Mn}$ and $\mathrm{Fe}$ at this depth. Molar ratio calculations for these particles, however, show two distinct populations: a high $\mathrm{Mn}$, low $\mathrm{Fe}$ population with a $\mathrm{Mn}: \mathrm{Fe}$ molar ratio averaging approximately 3 , and a high $\mathrm{Fe}$, low Mn population with a molar ratio averaging approximately 0.3 . Individual molar ratios span from 31.14 to $0.07 \mathrm{Mn}$ :Fe. 
$20 \mathrm{~m}$
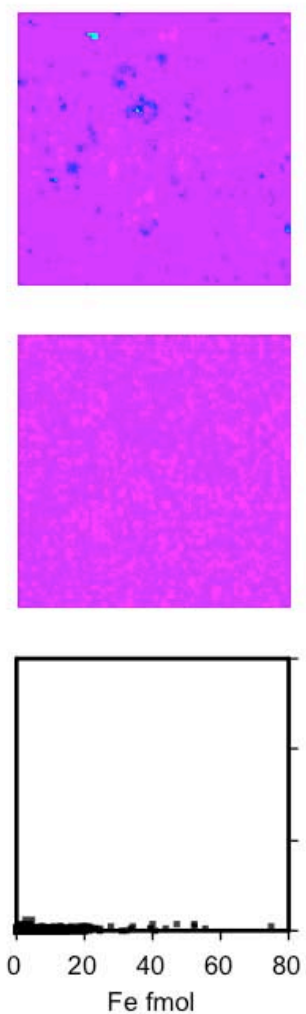

$118.6 \mathrm{~m}$
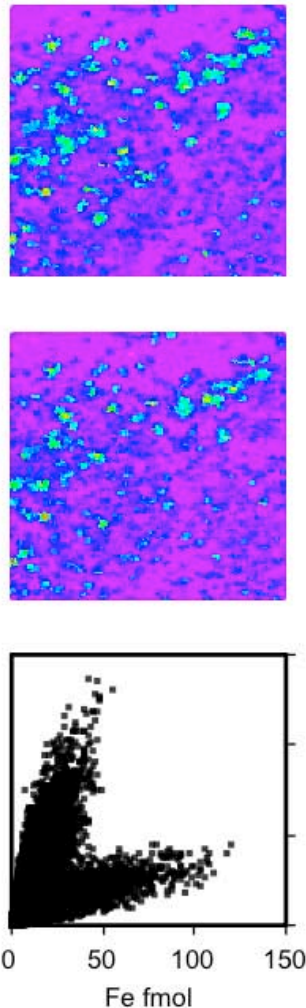

$123.5 \mathrm{~m}$
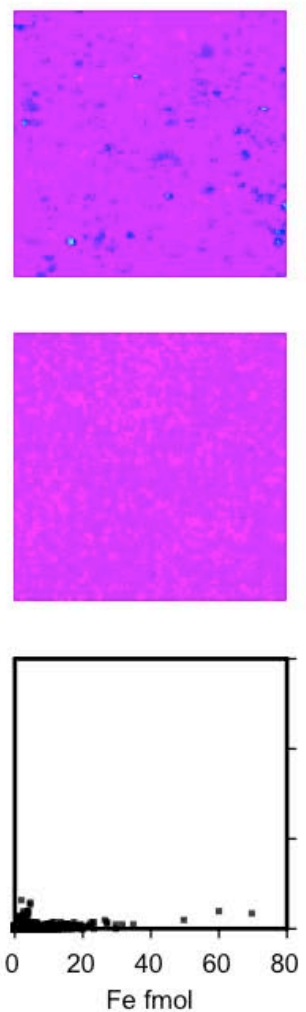

$129 \mathrm{~m}$
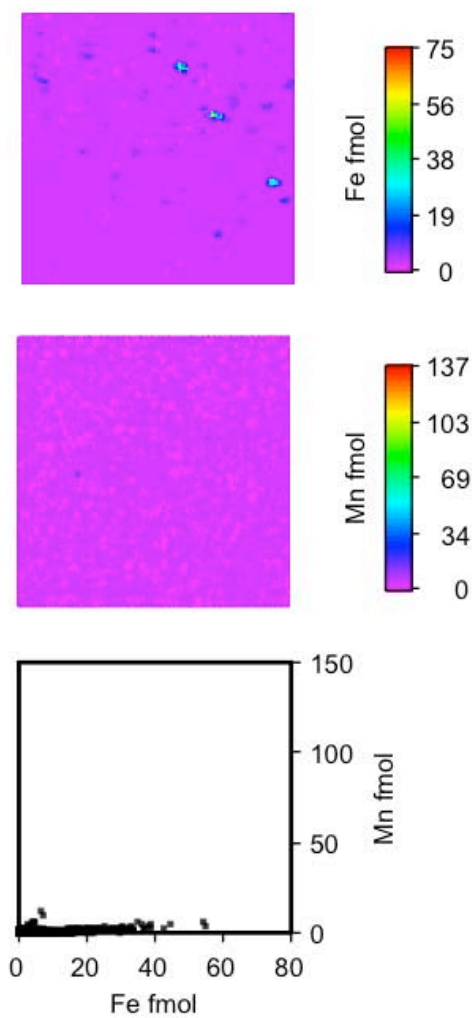

Fig. 6. Two-dimensional contour maps $\left(1 \mathrm{~mm}^{2}\right)$ acquired by synchrotron-based $\mu$ XRF showing Mn and Fe associations. The bottom row of graphs show scatter plots of fmol Fe versus fmol Mn from the $\mu$ XRF maps. Oxides are formed near $118.6 \mathrm{~m}$, and two distinct populations are visible there. There is a background population of high Fe-low Mn particles visible at all other depths.

The high Mn:Fe particles likely represent the authigenic Mn oxides formed by $\mathrm{Mn}$ oxidation with oxygen. The high $\mathrm{Fe}$ particles with low Mn content are likely the product of $\mathrm{Fe}$ oxidation, as $\mathrm{Fe}(\mathrm{II})$ is oxidized by Mn oxides. The small amounts of associated Mn may be adsorbed on the surface, a minor coprecipitate, or incorporated into the Fe oxide structure. At all other depths analyzed, there is a small, background population of Fe particles with no discernable Mn. Chemical extractions, $\mu$ XRF maps, and molar ratio plots all indicate this is a poorly reactive "background" of Fe particles supplied from the catchment.

\subsection{Oxidation of Mn}

Experimental rates of $\mathrm{Mn}$ oxidation were determined by incubating lake water from $118,119,120$, and $121 \mathrm{~m}$ depth at roughly in situ temperatures and augmented with $\sim 40 \mathrm{moll}^{-1} \mathrm{Mn}$ (II). While the addition of $\mathrm{Mn}$ (II) up to $40 \mu \mathrm{moll}^{-1}$ is a 2.5 to 7 fold increase of ambient $\mathrm{Mn}$ (II) concentrations depending on depth and could cause artifacts in the incubations, e.g. microbial community changes, mineral property changes because of increased $\mathrm{Mn}$ (II) surface sorption, and saturation of Mn oxidizing enzymes, the re- sults are still valuable. The results of these incubations are shown in Fig. 8a, and the average oxidation rates calculated $(\partial[\mathrm{Mn}(\mathrm{II})] / \partial t)$ from these experiments are given with relative standard deviations in Table 3. An initial decrease in Mn(II) in the $118 \mathrm{~m}$ incubations may be Mn sorption onto Fe and Mn oxides present at this depth in the water column, as no further change is observed. The oxidation rates are highest in the 120 and $121 \mathrm{~m}$ depth incubations, which we conclude reflects the relative abundance of Mn oxidizing microbes at this depth. No Mn oxidation occurs in controls amended with formaldehyde or at $118 \mathrm{~m}$, where $\mathrm{Mn}$ is normally absent from the water column (Fig. 3). These observations support our conclusion that Mn oxidation is biologically catalyzed. Averaging the experimental rates from 119, 120, and $121 \mathrm{~m}$ gives a mean rate of $0.15 \pm 0.03 \mu \mathrm{moll}^{-1} \mathrm{~d}^{-1}$. The long incubation times and higher than ambient $\mathrm{Mn}$ (II) concentrations, however, may have produced artifacts in our rate observations. Recalculating Mn oxidation rates based only on the first two time points for 119-121 m gives higher rates of $0.36-0.72 \mu \mathrm{moll}^{-1} \mathrm{~d}^{-1}$. 


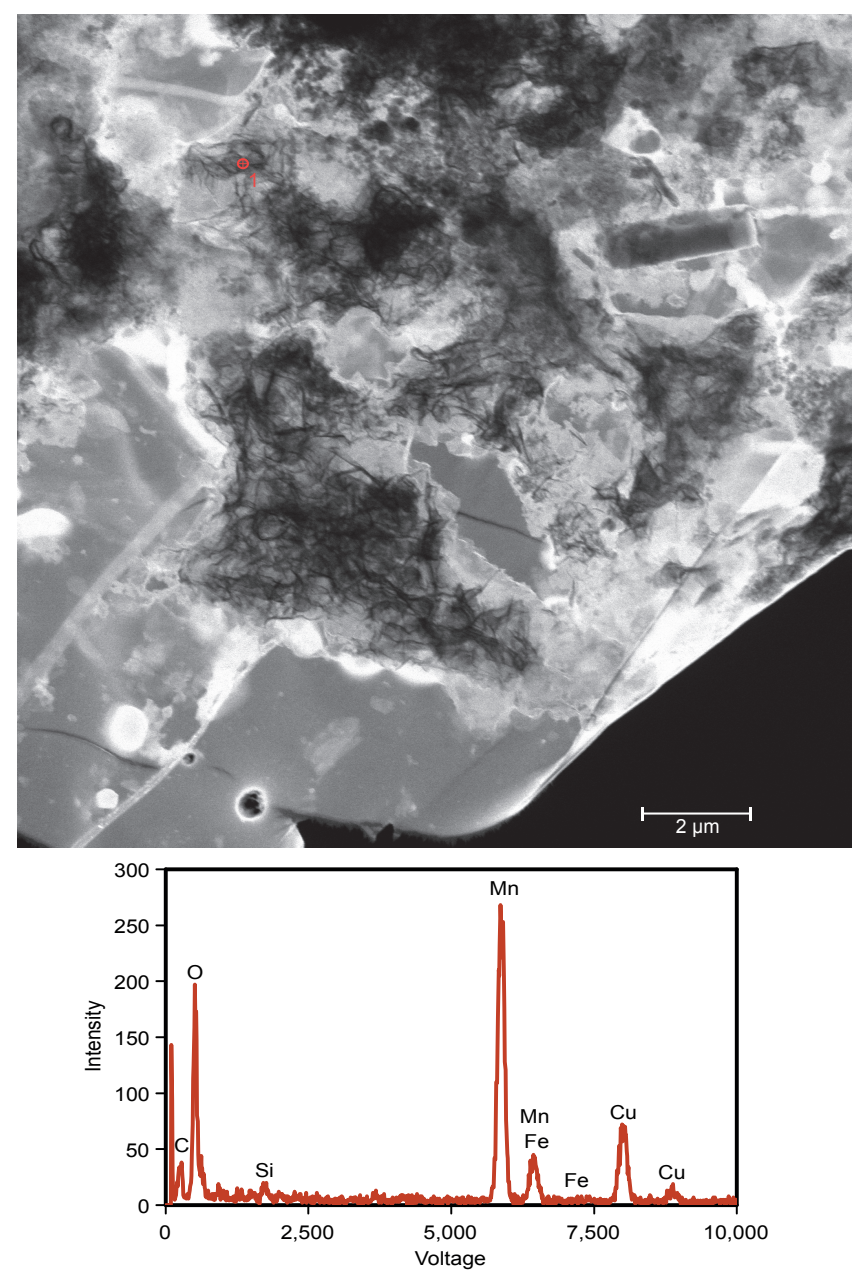

Fig. 7. TEM micrograph of particles collected from $118.6 \mathrm{~m}$ depth. Aggregates of dark, fibrous minerals seen in the TEM image are similar in morphology to birnessite (Cheney et al., 2008), and an EDS spectrum collected from the point indicated with red crosshairs shows predominately $\mathrm{Mn}$ and $\mathrm{O}$ present.

\subsection{Mn(II) mineral precipitation}

In the bottom waters of Lake Matano, the Mn(II) concentration decreases to $6 \mu \mathrm{moll}^{-1}$ (Fig. 3). Our deepest water column particle samples were from $129 \mathrm{~m}$ where we found no Mn particles, but the drawdown in Mn(II) is deeper than this. Removal of dissolved Mn(II) at depth is expected, since the waters reach saturation with respect to a variety of $\mathrm{Mn}(\mathrm{II})$ containing minerals, consistent with thermodynamic saturation calculations (Table 4). Indeed, the bottom waters (at $200 \mathrm{~m}$ ) of Lake Matano are oversaturated with respect to rhodochrosite, pseudo kutnahorite, and the hypothetical mineral, $\mathrm{MnHPO}_{4}$ (assuming $25^{\circ} \mathrm{C}$ and $1 \mathrm{~atm}$ pressure), with pseudo kutnahorite having the saturation index closest to zero and, therefore, being the most likely mineral buffering bottom water dissolved $\mathrm{Mn}$ (II) concentrations. Further work is needed to verify these predictions.
Table 3. Mn oxidation rates.

\begin{tabular}{lccccc}
\hline$\left(\mu \mathrm{mol} \mathrm{l}^{-1} \mathrm{~d}^{-1}\right)$ & $\begin{array}{c}\text { Avg } \\
\text { Control }\end{array}$ & $118 \mathrm{~m}$ & $119 \mathrm{~m}$ & $120 \mathrm{~m}$ & $121 \mathrm{~m}$ \\
\hline Mn ox rate & 0.011 & 0.050 & 0.104 & 0.140 & 0.190 \\
Std. Dev. & 0.009 & 0.028 & 0.023 & 0.024 & 0.050 \\
\hline
\end{tabular}

\subsection{Modeling}

We used flux calculations and a one dimensional (1-D) reaction transport model to explore $\mathrm{Mn}$ dynamics in Lake Matano. The 1-D reaction transport model allows us to estimate rates of biogeochemical processes and sinking rates of particles in the water column. It also allows us to test our experimental rate measurements by using the constants derived from the incubations to simulate the in situ profiles. The 1-D model uses AQUASIM software (Reichert, 1994), and assumes steady-state conditions and no lateral input. The model considers transport of Mn solutes and solids by turbulent eddy diffusion, sinking of Mn particles through the water column, reduction of particulate $\mathrm{Mn}$ oxides to $\mathrm{Mn}$ (II) in the anoxic water column by $\mathrm{Fe}$ (II) and other mechanisms, oxidation of $\mathrm{Mn}(\mathrm{II})$ by $\mathrm{O}_{2}$ above the redoxcline, and precipitation of a $\mathrm{Mn}$ (II) mineral in the deep water. The eddy diffusion rates were specified explicitly based on their depth distribution in Lake Matano reported in an earlier study (Katsev et al., 2010). These diffusion rates carry an uncertainty factor of $\sim 5$. Rate expressions used in the model are presented in Table 5. The concentrations of $\mathrm{Fe}$ (II) in the model rate expressions were specified as functions of depth from their measured distributions (Fig. 3). Oxidation of $\mathrm{Mn}$ (II) by $\mathrm{O}_{2}$ was represented by a first order rate equation, to best compare the model rate constant to values obtained in our incubation experiments and from the literature.

Model parameters were adjusted to fit the measured profiles (Fig. 3). Sensitivity of the model to the reaction rate constants is illustrated in Fig. 9. The corresponding parameters for each run are presented in Table 6. The Mn(II) oxidation rate constant, $k_{\mathrm{MnOx}}$, was specified based on the results of our incubations and varied to demonstrate the best fit and the sensitivity of the model to the constant. The rate constant for Mn oxide reduction by $\mathrm{Fe}(\mathrm{II}), k_{\mathrm{MnRedFe}}$, was chosen from values reported in sediment modeling studies (Hunter et al., 1998; Van Cappellen and Wang, 1995, 1996) for lack of experimental values in comparable environments. The other Mn oxide reduction rate constant, $k_{\mathrm{MnRed}}$, represents Mn oxide reduction by all other pathways. The rate constant for precipitation of the $\mathrm{Mn}$ (II) mineral phase was obtained by fitting the measured $\mathrm{Mn}$ (II) profile.

The model best fits the field measurements in runs 4 and 5 . These fits resulted from the following parameter values: an 

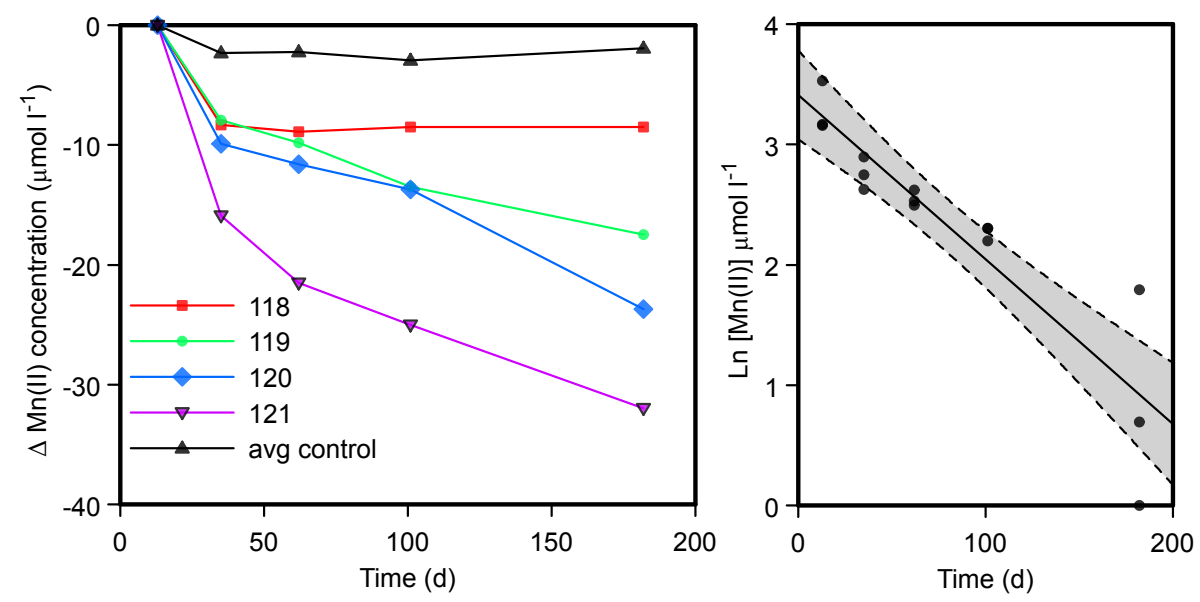

Fig. 8. Left panel: Mn oxidation rate incubation data showing Mn oxidation (as dissolved Mn disappearance) at 119 to $121 \mathrm{~m}$ depth. Incubations of water from $118 \mathrm{~m}$ are not significantly different than the controls killed with formaldehyde. Right panel: natural log of Mn(II) concentration versus time from 119-121 m, demonstrating the applicability of first order reaction kinetics in Lake Matano.

Table 4. Saturation Indices (SI) of Mn minerals in Lake Matano's bottom waters calculated as $\mathrm{SI}=\log \left(\mathrm{IAP} / K_{\mathrm{Sp}}\right)$, where IAP is the ion activity product and $K_{\mathrm{sp}}$ is the solubility product, calculated assuming $25^{\circ} \mathrm{C}$ and 1 atm pressure. Calcite and $\mathrm{MnHPO}_{4} K_{\mathrm{sp}}$ were obtained from the MINTEQA2 thermodynamic database.

\begin{tabular}{lllrl}
\hline Mineral & Chemical formula & $K_{\text {sp }}$ & SI & $K_{\text {sp Reference }}$ \\
\hline Rhodochrosite & $\mathrm{MnCO}_{3}$ & $10^{-12.51}$ & 1.243 & Jensen et al. (2002) \\
Kutnahorite & $\mathrm{CaMn}\left(\mathrm{CO}_{3}\right)_{2}$ & $10^{-19.84}$ & -0.862 & Mucci (1991) \\
Pseudo Kutnahorite & $\mathrm{CaMn}\left(\mathrm{CO}_{3}\right)_{2}$ & $10^{-20.0}$ & 0.068 & Mucci (2004) \\
Calcite & $\mathrm{CaCO}_{3}$ & $10^{-8.48}$ & -0.960 & Allison et al. (1991) \\
- & $\mathrm{MnHPO}_{4}$ & $10^{-25.4}$ & 8.050 & Allison et al. (1991) \\
\hline
\end{tabular}

Table 5. Reactions and Rate laws used in the 1-D model.

\begin{tabular}{ll}
\hline Reaction & Rate law \\
\hline $2 \mathrm{Mn}^{2+}+\mathrm{O}_{2}+2 \mathrm{H}_{2} \mathrm{O} \rightarrow 2 \mathrm{MnO}_{2}+4 \mathrm{H}^{+}$ & $R=k_{\mathrm{MnOx}}[\mathrm{Mn}(\mathrm{II})]$ \\
$2 \mathrm{Fe}^{2+}+\mathrm{MnO}_{2}+2 \mathrm{OH}^{-} \rightarrow 2 \mathrm{FeOOH}+\mathrm{Mn}^{2+}$ & $R=k_{\mathrm{MnRedFe}}[\mathrm{Fe}(\mathrm{II})]\left[\mathrm{MnO}_{2}\right]$ \\
$\mathrm{MnO}_{2}+\mathrm{C}_{\mathrm{org}} \rightarrow \mathrm{Mn}^{2+}+\mathrm{CO}_{2}$ & $R=k_{\mathrm{MnRed}}\left[\mathrm{MnO}_{2}\right]$ \\
$\mathrm{Mn}^{2+} \rightarrow \mathrm{Mn}(\mathrm{II})$ mineral & $R=k_{\mathrm{MnPrec}}\left([\mathrm{Mn}(\mathrm{II})]-\left[\mathrm{Mn}(\mathrm{II})_{\text {deep }}\right]\right)$ \\
\hline
\end{tabular}

input of Mn to the lake surface of $120 \mu \mathrm{mol} \mathrm{m}{ }^{-2} \mathrm{~d}^{-1}$; a Mn oxidation first order rate constant of $0.1 \mathrm{~d}^{-1}$; a settling velocity for Mn particles on the order of $4.5 \mathrm{~m} \mathrm{~d}^{-1}$; and a first order $\mathrm{Mn}$ (II) mineral formation rate of $0.0005 \mathrm{~d}^{-1}$. The settling velocity of the Mn oxide particles was set in order to meet mass balance requirements and corresponds to Stoke's law of settling of a birnessite (density of $3.4 \mathrm{~g} \mathrm{~cm}^{-3}$ ) particle of $5 \mu \mathrm{m}$ diameter. To explain the sharp gradient in particulate $\mathrm{Mn}$ at the redoxcline, a sufficiently high rate of $\mathrm{Mn}$ reduction was achieved by two combinations of Mn reduction pathways: e.g. with a second order rate constant for Mn oxide reduction by $\mathrm{Fe}(\mathrm{II})$ of $1000 \mathrm{~m}^{3} \mathrm{~mol}^{-1} \mathrm{~d}^{-1}$ and a first order rate constant for other pathways of $50 \mathrm{~d}^{-1}$ (run 4). Alternatively, the rate constant for $\mathrm{Mn}$ oxide reduction by $\mathrm{Fe}(\mathrm{II})$ could be $10000 \mathrm{~m}^{3} \mathrm{~mol}^{-1} \mathrm{~d}^{-1}$ and the rate constant for other pathways $5 \mathrm{~d}^{-1}$ (run 5). Trying to fit the profiles using only one of these pathways resulted in unrealistic values of rate constants. All simulated profiles in Fig. 9 exhibited epilimnetic Mn oxide concentrations higher than the observed values, which suggests that the Mn oxides are supplied into the lake predominantly as slumps along the steep bottom slopes, rather than through the lake surface. This is consistent with 

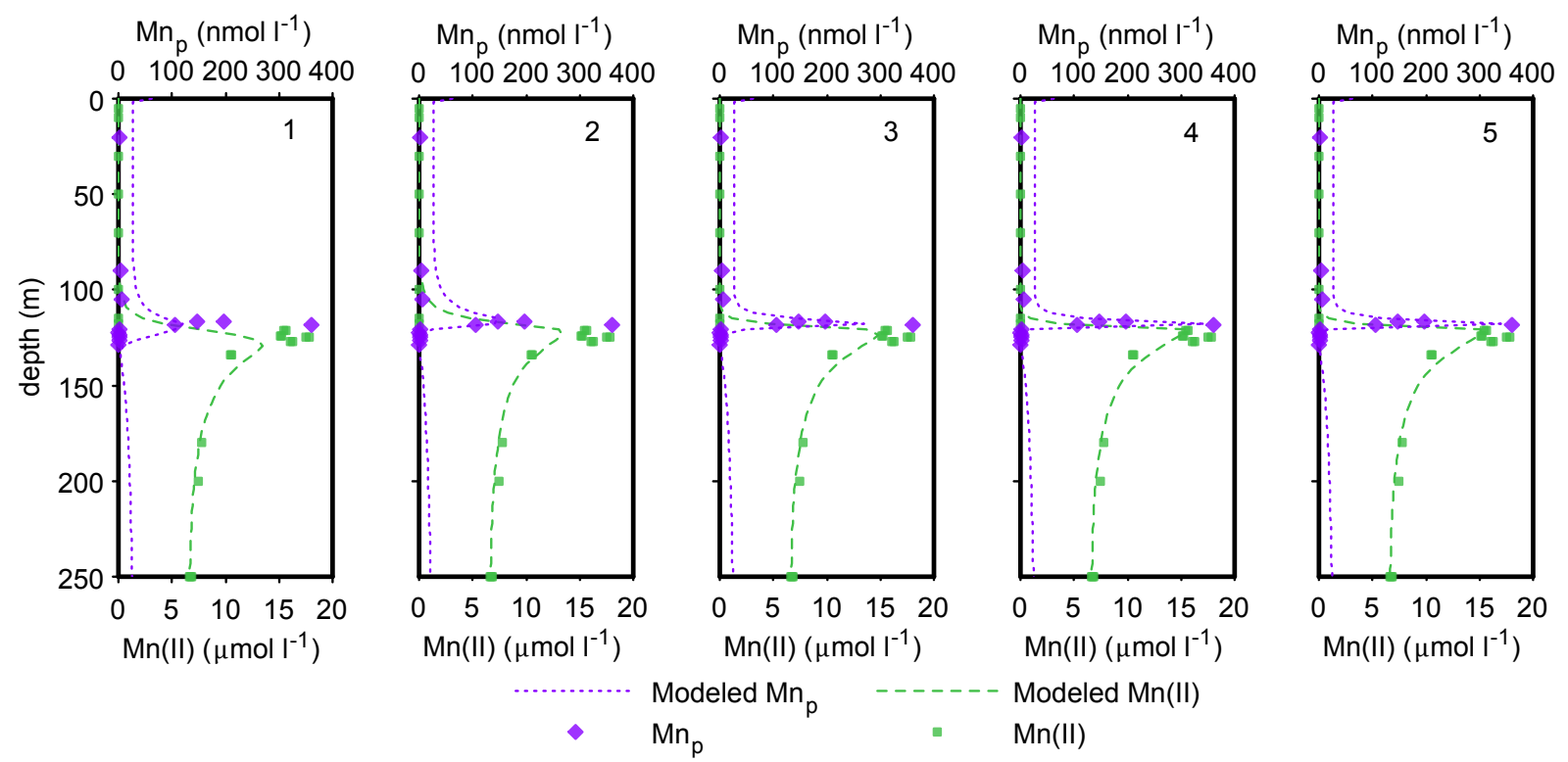

Fig. 9. Five modeled profiles of dissolved and particulate Mn using parameters specified in Table 6. Points represent field data, while the dashed lines are the model.

Table 6. 1-D Model parameters.

\begin{tabular}{llllllll}
\hline & 1 & 2 & 3 & 4 & 5 & Units & Lit. value \\
\hline$k_{\mathrm{MnOx}}$ & 0.015 & 0.015 & 0.1 & 0.1 & 0.1 & $\mathrm{~d}^{-1}$ & $0.01-0.7^{\mathrm{c}}$ \\
$k_{\mathrm{MnRedFe}}$ & 100 & 1000 & 1000 & 1000 & 10000 & $\mathrm{~m}^{3} \mathrm{~mol}^{-1} \mathrm{~d}^{-1}$ & $<2000^{\mathrm{a}}$ \\
$k_{\mathrm{MnRed}}$ & 0 & 0 & 5 & 50 & 5 & $\mathrm{~d}^{-1}$ & 1 to $6^{\mathrm{b}}$ \\
$k_{\mathrm{Mn}(\mathrm{II}) \min }$ & $5 \times 10^{-4}$ & $5 \times 10^{-4}$ & $5 \times 10^{-4}$ & $5 \times 10^{-4}$ & $5 \times 10^{-4}$ & $\mathrm{~d}^{-1}$ & - \\
$V_{\mathrm{MnO}_{2} \text { settle }}$ & 4.5 & 4.5 & 4.5 & 4.5 & 4.5 & $\mathrm{~m} \mathrm{~d}^{-1}$ & - \\
\hline
\end{tabular}

a Van Cappellen and Wang (1996)

b Stumm and Morgan (1996)

c Tebo and Emerson (1985) and Balikungeri et al. (1985) for endmembers, Johnson et al. (1991) for a compilation

previous conclusions about the supply of $\mathrm{Fe}$ to the lake's deep waters and sediments (Crowe et al., 2008b). The impossibility of adequately representing lateral fluxes in a 1-D model results in a higher-than-observed epilimnetic concentration of particulate $\mathrm{Mn}$, but regardless of a lateral or vertical Mn oxide source, fluxes away from the $\mathrm{Mn}$ (II) concentration peak and the corresponding transformation rates are still valid.

Flux calculations allow estimation of Mn recycling rates, which in turn allow us to constrain the potential contributions of various reductants in the reduction of authigenic $\mathrm{Mn}$ oxides, within a factor of 5 . Fluxes of solutes, $J$, were calculated based on concentration gradients measured in 2009 and eddy diffusivity coefficients, $K_{z}$ (Table 7), as

$J=-K_{z} \cdot \frac{\partial[\mathrm{Mn}(\mathrm{II})]}{\partial z}$

where concentration gradients were calculated as the slope of a linear regression computed for depth versus concentration at each given depth interval. Using a steady state assumption, the volume specific rate calculated from the upward flux of $\mathrm{Mn}(\mathrm{II})$ is

$R_{\mathrm{MnOx}}=\frac{J}{z}$

Assuming a $3 \mathrm{~m}$ zone of oxidation (118.5 to $121.5 \mathrm{~m}$ ), the measured gradients yield an average rate of $R_{\mathrm{MnOx}}=$ $0.27 \mu \mathrm{moll}^{-1} \mathrm{~d}^{-1}$, consistent with measured initial rates of oxidation. Using this rate, a range of $\mathrm{Mn}$ (II) concentrations from $1-15 \mu \mathrm{mol} \mathrm{l}^{-1}$, and assuming a pseudo first order rate law:

$R_{\mathrm{MnOx}}=k_{\mathrm{OX}} \cdot[\mathrm{Mn}(\mathrm{II})]$

we calculate a range of $\mathrm{Mn}$ oxidation rate constants $\left(k_{\mathrm{ox}}\right)$ from $0.27 \mathrm{~d}^{-1}$ to $0.01 \mathrm{~d}^{-1}$. As discussed above, incubations of lake water augmented with $\mathrm{Mn}$ (II) suggested Mn oxidation rate constants around $0.015 \mathrm{~d}^{-1}$, near the lower estimate 
Table 7. Flux calculation parameters.

\begin{tabular}{lrlrrl}
\hline & $\begin{array}{r}\text { Depth interval used } \\
\text { to calculate gradient }\end{array}$ & $\begin{array}{l}\text { Conc. gradient } \\
\left(\mu \mathrm{mol} \mathrm{l}^{-1} \mathrm{~m}^{-1}\right)\end{array}$ & $\begin{array}{c}K_{z} \\
\left(\mathrm{~m}^{2} \mathrm{~s}^{-1}\right)\end{array}$ & $\begin{array}{r}\text { Diffusive Flux } \\
\left(\mu \mathrm{mol} \mathrm{m}{ }^{-2} \mathrm{~d}^{-1}\right)\end{array}$ & $\begin{array}{l}\text { Volume specific rate } \\
\left(\mu \mathrm{mol} \mathrm{1} \mathrm{d}^{-1}\right)\end{array}$ \\
\hline $\mathrm{Mn}^{2+}$ & $117-125 \mathrm{~m}$ & 1.9 & $5 \times 10^{-6}$ & 821 & $0.27,0.15^{*}$ \\
$\mathrm{Mn}^{2+}$ & $127-250 \mathrm{~m}$ & 0.07 & $1 \times 10^{-5}$ & -61 & 0.01 \\
$\mathrm{O}_{2}$ & $118.5-125 \mathrm{~m}$ & 1.0 & $5 \times 10^{-6}$ & -432 & 0.06 \\
$\mathrm{Fe}^{2+}$ & $120-125 \mathrm{~m}$ & 2.3 & $5 \times 10^{-6}$ & 994 & 0.14 \\
$\mathrm{CH}_{4}$ & $100-160 \mathrm{~m}$ & 9.7 & $5 \times 10^{-6}$ & 4190 & 0.60 \\
$\mathrm{NH}_{4}^{+}$ & $105-160 \mathrm{~m}$ & 2.3 & $5 \times 10^{-6}$ & 998 & 0.14 \\
\hline
\end{tabular}

All calculations are based on data collected in 2009 except $\mathrm{CH}_{4}$ and $\mathrm{NH}_{4}^{+}$, which were taken from Crowe et al. (2011). Mn flux up (positive, driven by Mn(II) oxidation) is calculated assuming a $3 \mathrm{~m}$ zone of oxidation. Other reactions assume a $7 \mathrm{~m}$ active zone. ${ }^{*}$ Volume specific rates were also calculated from the Mn oxidation incubations.

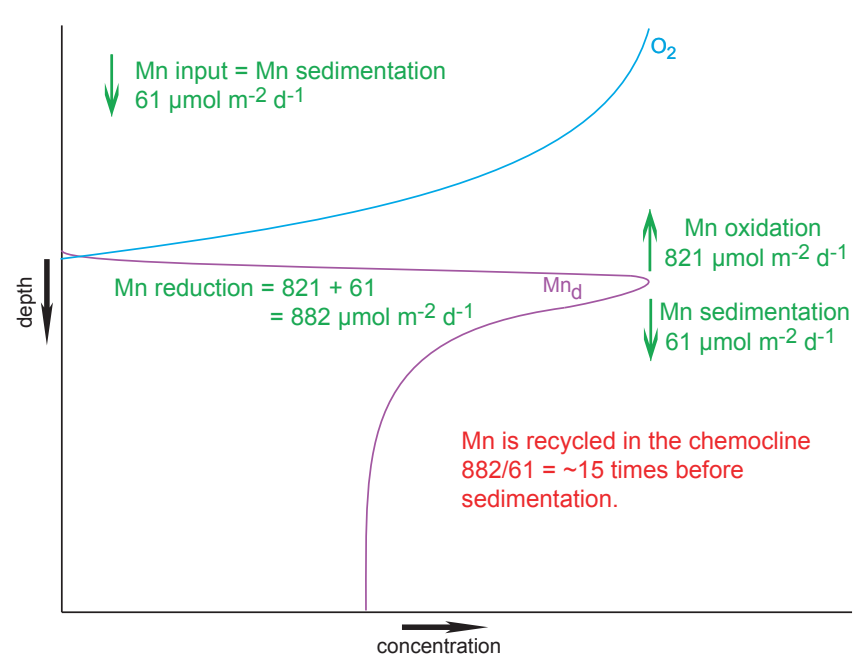

Fig. 10. Calculated fluxes and recycling rates of $\mathrm{Mn}$ in Lake Matano.

of the range calculated here. Using a $k_{\mathrm{ox}}$ value of $0.1 \mathrm{~d}^{-1}$ (chosen from within these derived values) in our 1-D model, we are able to reproduce the $\mathrm{Mn}$ (II) and particulate Mn oxide profiles (Fig. 9).

The Mn oxidation rate constant used in the best-fit model $\left(0.1 \mathrm{~d}^{-1}\right)$ is nearly an order of magnitude greater than the one estimated by our incubations $\left(0.015 \mathrm{~d}^{-1}\right)$. The incubations, by design, were cut off from sources of substrates other than $\mathrm{Mn}(\mathrm{II})$ and $\mathrm{O}_{2}$ and were given no organic carbon to sustain natural populations of heterotrophic bacteria. As the incubations lasted $>180$ days, this isolation may have affected the ability of populations to, for example, produce and excrete superoxide or maintain enzymatic heme peroxidase activity. Therefore, while the incubations allowed us to ensure that $\mathrm{Mn}(\mathrm{II})$ oxidation was biologically catalyzed, they likely underestimate in situ rates and rate constants.

\subsection{Recycling rates and potential reductants}

Comparing calculated fluxes of $\mathrm{Mn}$ (II) allows us to quantify water column $\mathrm{Mn}$ recycling and constrain the potential reductants of Mn oxides (Fig. 10). Assuming pseudosteady state, the rate of Mn leaving the water column must equal the rate of Mn input. Thus, we can equate the downward flux of $\mathrm{Mn}$ (II) (driven by $\mathrm{Mn}$ (II) mineral precipitation/sedimentation), $61 \mu \mathrm{mol} \mathrm{m} \mathrm{m}^{-2} \mathrm{~d}^{-1}$ (Table 7), with the total flux of $\mathrm{Mn}$ into the system. We assume Mn enters the system in oxidized form. Since Mn leaves the water column as a Mn(II) mineral, all the oxidized Mn must ultimately be reduced. Mn reduction can then be calculated as the sum of the upward (oxidative) and downward (precipitation driven, which is equal to the oxidized $\mathrm{Mn}$ input) fluxes $\left(821+61=882 \mu \mathrm{mol} \mathrm{m} \mathrm{m}^{-2} \mathrm{~d}^{-1}\right)$. This rate of $\mathrm{Mn}$ reduction is a factor of 4 higher than estimated rates of Fe reduction in Lake Matano (Crowe et al., 2011). Mn reduction is roughly 15 times the Mn input, suggesting that $\mathrm{Mn}$ is recycled at least 15 times within the water column before removal by sedimentation.

As noted by reactions in Table $1, \mathrm{Mn}$ oxides can be reduced using a number of electron donors. Figure 3 shows the concentration profiles of some of these reductants in Lake Matano, where $\mathrm{Fe}(\mathrm{II}), \mathrm{NH}_{4}^{+}$, and $\mathrm{CH}_{4}$ are all in abundant supply. Fe(II) is first detectable $\left(>1 \mu \mathrm{mol} \mathrm{l}^{-1}\right)$ at $121 \mathrm{~m}$, below the peak in Mn oxides at $118.6 \mathrm{~m}$. By $250 \mathrm{~m}, \mathrm{Fe}(\mathrm{II})$ reaches a concentration of $140 \mu \mathrm{mol}^{-1}$. Both $\mathrm{CH}_{4}$ and $\mathrm{NH}_{4}^{+}$ display similar shaped concentration profiles, with maximum concentrations of $1.3 \mathrm{mmoll}^{-1}$ and $200 \mu \mathrm{moll}^{-1}$, respectively, below $250 \mathrm{~m}$ depth. $\mathrm{CH}_{4}$, as opposed to $\mathrm{Fe}(\mathrm{II})$, coexists with oxygen. Other potential electron donors are organic carbon and sulfide.

Based on the distribution and oxidation state of Mn particles (Figs. 3 and 5), Mn oxides are formed near the chemocline and reduced in the water column by $120.5 \mathrm{~m}$. Comparing the Mn reductive flux with the upward flux of $\mathrm{Fe}(\mathrm{II})$ across the specific depth interval where Fe(II) may contribute to Mn reduction (119 to $121 \mathrm{~m}$ ) shows that $\mathrm{Fe}(\mathrm{II})$ may 
account for up to $56 \%$ of $\mathrm{Mn}$ reduction. There is, of course, ample $\mathrm{Fe}(\mathrm{II})$ in the deep basin to reduce all the Mn oxides, but the upward $\mathrm{Fe}$ (II) fluxes calculated in the vicinity of Mn reduction are not sufficient; therefore, there must be an additional reductant for Mn oxides.

In Lake Matano's chemocline, area-specific sulfate reduction rates are $19 \mu \mathrm{mol} \mathrm{m}^{-2} \mathrm{~d}^{-1}$ (Crowe et al., 2008b). If all sulfide produced by sulfate reduction is in turn oxidized back to sulfate by Mn oxides, sulfide could account for $9 \%$ of total $\mathrm{Mn}$ reduction. Since some sulfide precipitates as solid $\mathrm{Fe}$ sulfides (Crowe et al., 2008a), however, this is an overestimate. Organic carbon is also a known reductant for Mn oxides. In the epilimnion, primary production rates were measured at $3.8 \times 10^{-3} \mathrm{~mol} \mathrm{~m}^{2} \mathrm{~d}^{-1}$ in 2007 (Crowe et al., 2011). This should generate enough organic carbon to account for all $\mathrm{Mn}$ reduction, provided the organic carbon is not respired in the epilimnion. In the chemocline in 2009 , however, area specific carbon fixation rates are $9.9 \times 10^{-3} \mathrm{~mol} \mathrm{~m}^{-2} \mathrm{~d}^{-1}$. Therefore, there is ample organic carbon fixed in the vicinity of the chemocline to reduce the Mn oxides generated just above the redox boundary. Another thermodynamically favorable reaction involves oxidation of $\mathrm{NH}_{4}^{+}$via reduction of Mn oxides (Table 1). Theoretically, there is an ample $\mathrm{NH}_{4}^{+}$flux to account for all $\mathrm{Mn}$ reduction. To date, however, there is little experimental and environmental evidence for this process, and a detailed study found it absent from Mnrich, marine sediments (Thamdrup and Dalsgaard, 2000). As previously proposed (Crowe et al., 2011), we suggest that $\mathrm{CH}_{4}$ is an additional, potential reductant. While we have shown that Mn oxides are supplied with ample reductants, $\mathrm{CH}_{4}$ is lacking oxidants (Crowe et al., 2011). At a rate of $882 \mu \mathrm{mol} \mathrm{m}^{-2} \mathrm{~d}^{-1}$, Mn reduction could account for $5.3 \%$ of $\mathrm{CH}_{4}$ oxidation in Lake Matano. If the maximum Mn reduction from the $\mathrm{Fe}$ (II) flux is first subtracted, Mn oxide reduction by $\mathrm{CH}_{4}$ could be estimated to oxidize $\sim 2.3 \%$ of the total $\mathrm{CH}_{4}$ flux.

\section{Conclusions and geobiological implications}

Mn oxidation occurs in a ferruginous chemocline at rates similar to other diverse environments. This suggests that $\mathrm{Mn}$ oxidation is insensitive to environmental conditions and may be controlled by a single, common mechanism. Birnessite produced from Mn oxidation settles less than $2 \mathrm{~m}$ in the water column before it is completely reduced, likely by a combination of $\mathrm{Fe}(\mathrm{II}), \mathrm{H}_{2} \mathrm{~S}$, organic matter, and $\mathrm{CH}_{4}$. Pseudo kutnahorite precipitation is predicted to buffer the bottom water dissolved $\mathrm{Mn}(\mathrm{II})$ concentrations. Due to $\mathrm{Mn}$ recycling, $\mathrm{Mn}$ reduction rates exceed those of $\mathrm{Fe}$ despite the much lower concentrations of $\mathrm{Mn}$ in the water column. According to our findings, the kinetics of authigenic Mn oxide reduction in a ferruginous environment are so rapid that they prevent Mn oxide sedimentation through the underlying anoxic water column.
These conclusions could weigh heavily on our interpretation of Paleoproterozoic ocean water column chemistry from which large Mn formations were deposited. As far as current evidence suggests, $\mathrm{Mn}$ is oxidized only in the presence of $\mathrm{O}_{2}$, and most $\mathrm{Mn}$ in marine sedimentary $\mathrm{Mn}$ formations must have originally been deposited as Mn oxides (Calvert and Pedersen, 1996). Based on C isotope studies, it has been suggested that the carbonate in Mn carbonate minerals from these formations was produced during the diagenetic oxidation of organic matter during respiratory Mn reduction (Tsikos et al., 2003). As Mn oxides would be reduced in a ferruginous water column, we can conclude that the accumulation of Mn oxides in sediments, necessary for subsequent diagenetic Mn reduction, requires that water immediately overlying the sediments contained less $\mathrm{Fe}$ (II) than Mn, and the surface waters contained molecular oxygen. Additionally, $\mathrm{H}_{2} \mathrm{~S}$ reacts abiotically with $\mathrm{Mn}$ in much the same way as Fe(II) (Yao and Millero, 1993). Formation of Mn oxide deposits, therefore, would be most favorable in settings with bottom waters that have low concentrations of both $\mathrm{Fe}(\mathrm{II})$ and $\mathrm{H}_{2} \mathrm{~S}$, and perhaps even $\mathrm{CH}_{4}$. This scenario could be envisioned as the stratified ocean transitioned from a ferruginous to a euxinic one. The solubility of Fe sulfides is much lower than the solubility of Mn sulfides (Stumm and Morgan, 1996), so as Fe(II) is titrated from the oceans by increasing $\mathrm{H}_{2} \mathrm{~S}, \mathrm{Mn}$ (II) is left to accumulate. This stratified, manganous ocean would be poised to deposit large quantities of Mn oxides until the source of $\mathrm{H}_{2} \mathrm{~S}$ overwhelmed the source of iron and the oceans became euxinic. Furthermore, we can assume that the concentration of $\mathrm{Fe}(\mathrm{II})$ in these anoxic bottom waters was $<2$ times the concentration of $\mathrm{Mn}$ (II) and sulfide concentrations were $<4$ times the concentration of $\mathrm{Mn}$ (II) based on the stoichiometries of the reducing reactions seen in Table 1. The sources of $\mathrm{Fe}$ (weathering and hydrothermal) would still be active during the transitional, manganous ocean, explaining the presence of considerable $\mathrm{Fe}$ in most $\mathrm{Mn}$ deposits, whereas the concentration of $\mathrm{Mn}$ in Fe deposits is low because the ferruginous conditions preclude Mn oxide sedimentation. An alternative explanation would be that Mn-oxide sedimentation occurred in sediments overlain by waters containing low oxygen concentrations and substantial dissolved Mn(II) (Calvert and Pedersen, 1996). These potential scenarios are being further investigated.

Acknowledgements. The authors thank Alfonso Mucci, Bjørn Sundby, and Raymond P. Cox for inspiring discussions, Simon Poulton, Ellery Ingall, and Kirsten Habicht for reviews of the manuscript, as well as two anonymous reviewers. S. Nomosatryo, D. Rahim, and S. Rio are acknowledged for sampling and logistical support in Indonesia. PNC-CAT beamline scientists provided invaluable instruction. PNC/XSD facilities at the Advanced Photon Source, and research at these facilities, are supported by the US Department of Energy - Basic Energy Sciences, a Major Resources Support grant from NSERC, the University of Washington, Simon Fraser University, and the Advanced Photon Source. Use of the Advanced Photon Source, an Office of Science User Facility 
operated for the US Department of Energy (DOE) Office of Science by Argonne National Laboratory, was supported by the US DOE under Contract No. DE-AC02-06CH11357. David Moore is thanked for help with TEM analyses. Peter Søholt provided technical support. The authors are grateful to PT-INCO Tbk for inkind support. The Danish National Research Foundation provided funding for C. J., S. A. C., and D. E. C. S. K. and D. A. F. were supported by the National Science Foundation grant EAR-0844250.

Edited by: J. Middelburg

\section{References}

Alkire, R. W. and Rotella, F. J.: An incident-beam monitor for use in protein crystallography at a synchrotron source, J. Appl. Crystallogr., 30, 327-332, 1997.

Allison, J. D., Brown, D. S., and Novo-Gradac, K. J.: MINTEQA2/PRODEF2, A Geochemical Assessment Model for Environmental Systems: Version 3.0 User's Manual, EPA, Athens, 3-91, 1991.

Anderson, C. R., Johnson, H. A., Caputo, N., Davis, R. E., Torpey, J. W., and Tebo, B. M.: Mn(II) Oxidation Is Catalyzed by Heme Peroxidases in "Aurantimonas manganoxydans" Strain SI85-9A1 and Erythrobacter sp Strain SD-21, Appl. Environ. Microbiol., 75, 4130-4138, 2009.

Balikungeri, A., Robin, D., and Haerdi, W.: Manganese in natural waters 2. Evidence for microbiological oxidation of $\mathrm{Mn}(\mathrm{II})$, Toxicol. Environ. Chem., 9, 309-325, 1985.

Balistrieri, L. S., Murray, J. W., and Paul, B.: The Cycling of Iron and Manganese in the Water Column of Lake Sammamish, Washington, Limnol. Oceanogr., 37, 510-528, 1992.

Beal, E. J., House, C. H., and Orphan, V. J.: Manganese- and IronDependent Marine Methane Oxidation, Science, 325, 184-187, 2009.

Bratina, B. J., Stevenson, B. S., Green, W. J., and Schmidt, T. M.: Manganese reduction by microbes from oxic regions of the Lake Vanda (Antarctica) water column, Appl. Environ. Microbiol., 64, 3791-3797, 1998.

Brewer, P. G. and Spencer, D. W.: Colorimetric Determination of Manganese in Anoxic Waters, Limnol. Oceanogr., 16, 107-110, 1971.

Brouwers, G. J., Vijgenboom, E., Corstjens, P., De Vrind, J. P. M., and de Vrind-de Jong, E. W.: Bacterial Mn2+ oxidizing systems and multicopper oxidases: An overview of mechanisms and functions, Geomicrobiol. J., 17, 1-24, 2000.

Calvert, S. E. and Pedersen, T. F.: Sedimentary geochemistry of manganese: Implications for the environment of formation of manganiferous black shales, Econ. Geol. Bull. Soc., 91, 36-47, 1996.

Canfield, D. E., Jorgensen, B. B., Fossing, H., Glud, R., Gundersen, J., Ramsing, N. B., Thamdrup, B., Hansen, J. W., Nielsen, L. P., and Hall, P. O. J.: Pathways of Organic-Carbon Oxidation in 3 Continental-Margin Sediments, Mar. Geol., 113, 27-40, 1993.

Canfield, D. E., Kristensen, E., and Thamdrup, B.: Aquatic Geomicrobiology, in: Adv. Mar. Biol., edited by: Southward, A. J., Tyler, P. A., Young, C. M., and Fuiman, L. A., Elsevier, San Diego, 640 pp., 2005.

Chapnick, S. D., Moore, W. S., and Nealson, K. H.: Microbially mediated manganese oxidation in a fresh water lake, Limnol.
Oceanogr., 27, 1004-1014, 1982.

Cheney, M. A., Bhowmik, P. K., Qian, S. Z., Joo, S. W., Hou, W. S., and Okoh, J. M.: A New Method of Synthesizing Black Birnessite Nanoparticles: From Brown to Black Birnessite with Nanostructures, J. Nanomater., 8 pp., 763706, doi:10.1155/2008/763706, 2008.

Clement, B. G., Luther, G. W., and Tebo, B. M.: Rapid, oxygen-dependent microbial $\mathrm{Mn}(\mathrm{II})$ oxidation kinetics at submicromolar oxygen concentrations in the Black Sea suboxic zone, Geochim. Cosmochim. Ac., 73, 1878-1889, 2009.

Crowe, S. A., Pannalal, S. J., Fowle, D. A., Cioppa, M. T., Symons, D. T. A., Haffner, G. D., Fryer, B. J., McNeely, R., Sundby, B., and Hehanussa, P. E.: Biogeochemical cycling in Fe-rich sediments from Lake Matano, Indonesia, 11th International symposium on Water-Rock Interaction, Saratoga Springs, 27 June-7 July 2004, USA, 1185-1189, 2004.

Crowe, S. A., O’Neill, A. H., Weisener, C. G., Kulczycki, E., Fowle, D. A., and Roberts, J. A.: Reductive dissolution of trace metals from sediments, Geomicrobiol. J., 24, 157-165, 2007.

Crowe, S. A., Jones, C., Katsev, S., Magen, C., O’Neill, A. H., Sturm, A., Canfield, D. E., Haffner, G. D., Mucci, A., Sundby, B., and Fowle, D. A.: Photoferrotrophs thrive in an Archean Ocean analogue, P. Natl. Acad. Sci. USA, 105, 15938-15943, 2008 a.

Crowe, S. A., O’Neill, A. H., Katsev, S., Hehanussa, P., Haffner, G. D., Sundby, B., Mucci, A., and Fowle, D. A.: The biogeochemistry of tropical lakes: A case study from Lake Matano, Indonesia, Limnol. Oceanogr., 53, 319-331, 2008b.

Crowe, S. A., Katsev, S., Leslie, K., Sturm, A., Magen, C., Nomosatryo, S., Pack, M. A., Kessler, J. D., Reeburgh, W. S., Roberts, J. A., Gonzalez, J., Haffner, G. D., Mucci, A., Sundby, B., and Fowle, D. A.: The methane cycle in ferruginous Lake Matano, Geobiology, 9, 61-78, 2011.

Davison, W.: Iron and Manganese in Lakes, Earth-Sci. Rev., 34, 119-163, 1993.

De Vitre, R.: Multimethod characterization of the forms of iron, manganese, and sulfur in a eutrophic lake (Bret, Vaud), Ph.D. thesis, University of Geneva, 251 pp., 1986.

Dick, G. J., Clement, B. G., Webb, S. M., Fodrie, F. J., Bargar, J. R., and Tebo, B. M.: Enzymatic microbial Mn(II) oxidation and Mn biooxide production in the Guaymas Basin deep-sea hydrothermal plume, Geochim. Cosmochim. Ac., 73, 6517-6530, 2009.

Duckworth, O. W., Bargar, J. R., and Spositio, G.: Sorption of ferric iron from ferrioxamine $\mathrm{B}$ to synthetic and biogenic layer type manganese oxides, Geochim. Cosmochim. Ac., 72, 3371-3380, 2008 .

Friedl, G., Wehrli, B., and Manceau, A.: Solid phases in the cycling of manganese in eutrophic lakes: New insights from EXAFS spectroscopy, Geochim. Cosmochim. Ac., 275-290, 1997.

Froelich, P. N., Klinkhammer, G. P., Bender, M. L., Luedtke, N. A., Heath, G. R., Cullen, D., Dauphin, P., Hammond, D., Hartman, B., and Maynard, V.: Early Oxidation of Organic-Matter in Pelagic Sediments of the Eastern Equatorial Atlantic - Suboxic Diagenesis, Geochim. Cosmochim. Ac., 43, 1075-1090, 1979.

Golightly, J. P.: Nickeliferous Laterite Deposits, Econ. Geol., 75th Aniversary Volume, 710-735, 1981.

Hunter, K. S., Wang, Y. F., and Van Cappellen, P.: Kinetic modeling of microbially-driven redox chemistry of subsurface environments: coupling transport, microbial metabolism and geochemistry, J. Hydrol., 209, 53-80, 1998. 
Jensen, D. L., Boddum, J. K., Tjell, J. C., and Christensen, T. H.: The solubility of rhodochrosite $\left(\mathrm{MnCO}_{3}\right)$ and siderite $\left(\mathrm{FeCO}_{3}\right)$ in anaerobic aquatic environments, Appl. Geochem., 17, 503$511,2002$.

Johnson, C. A., Ulrich, M., Sigg, L., and Imboden, D. M.: A mathematical-model of the manganese cycle in a seasonally anoxic lake, Limnol. Oceanogr., 36, 1415-1426, 1991.

Katsev, S., Crowe, S. A., Mucci, A., Sundby, B., Nomosatryo, S., Haffner, G. D., and Fowle, D. A.: Mixing and its effects on biogeochemistry in the persistently stratified, deep, tropical Lake Matano, Indonesia, Limnol. Oceanogr., 55, 763-776, 2010.

Kepkay, P. E.: Kinetics of Microbial Manganese Oxidation and Trace-Metal Binding in Sediments - Results from an Insitu Dialysis Technique, Limnol. Oceanogr., 30, 713-726, 1985.

Krauskopf, K. B.: Separation of Manganese from Iron in Sedimentary Processes, Geochim. Cosmochim. Ac., 12, 61-84, 1957.

Learman, D. R., Voelker, B. M., Vazquez-Rodriguez, A. I., and Hansel, C. M.: Formation of manganese oxides by bacterially generated superoxide, Nat. Geosci., 4, 95-98, 2011.

Lovley, D. R.: Dissimilatory Fe(Iii) and Mn(Iv) Reduction, Microbiological Reviews, 55, 259-287, 1991.

Lovley, D. R. and Phillips, E. J. P.: Organic-Matter Mineralization with Reduction of Ferric Iron in Anaerobic Sediments, Appl. Environ. Microbiol., 51, 683-689, 1986.

Luther, G. W., Sundby, B., Lewis, B. L., Brendel, P. J., and Silverberg, N.: Interactions of manganese with the nitrogen cycle: Alternative pathways to dinitrogen, Geochim. Cosmochim. Ac., 61, 4043-4052, 1997.

Mucci, A.: The Solubility and Free-Energy of Formation of Natural Kutnahorite, Can. Mineral., 29, 113-121, 1991.

Mucci, A.: The behavior of mixed Ca-Mn carbonates in water and seawater: Controls of manganese concentrations in marine porewaters, Aquat. Geochem., 10, 139-169, 2004.

Murray, J. W., Codispoti, L. A., and Friederich, G. E.: OxidationReduction Environments: The suboxic zone in the Black Sea, in: Aquatic Chemistry, edited by: Huang, C. P., O'Melia, C., and Morgan, J. J., American Chemical Society, Washington, D.C., 157-176, 1995.

Neaman, A., Waller, B., Mouele, F., Trolard, F., and Bourrie, G.: Improved methods for selective dissolution of manganese oxides from soils and rocks, Eur. J. Soil Sci., 55, 47-54, 2004.

Postma, D.: Concentration of Mn and Separation from Fe in Sediments. 1. Kinetics and Stoichiometry of the Reaction between Birnessite and Dissolved Fe(Ii) at 10-Degrees-C, Geochim. Cosmochim. Ac., 49, 1023-1033, 1985.

Poulton, S. W. and Canfield, D. E.: Development of a sequential extraction procedure for iron: implications for iron partitioning in continentally derived particulates, Chem. Geol., 214, 209-221, 2005.

Ravel, B. and Newville, M.: Athena, Artemis, Hephaestus: Data Analysis for X-Ray Absorption Spectroscopy Using Ifeffit, J. Synchrotron Radiat., 12, 537-541, 2005.

Reichert, P.: Aquasim - a Tool for Simulation and Data-Analysis of Aquatic Systems, Water Sci. Technol., 30, 21-30, 1994.

Schippers, A., Neretin, L. N., Lavik, G., Leipe, T., and Pollehne, F.: Manganese(II) oxidation driven by lateral oxygen intrusions in the western Black Sea, Geochim. Cosmochim. Ac., 69, 2241$2252,2005$.
Slawyk, G., Collos, Y., and Auclair, J. C.: Use of $\mathrm{C}^{13}$ and $\mathrm{N}^{15}$ Isotopes for Simultaneous Measurement of Carbon and Nitrogen Turnover Rates in Marine-Phytoplankton, Limnol. Oceanogr., 22, 925-932, 1977.

Stookey, L. L.: Ferrozine - a New Spectrophotometric Reagent for Iron, Anal. Chem., 42, 779-781, 1970.

Stumm, W. and Morgan, J. J.: Aquatic Chemistry: Chemical Equillibria and Rates in Natual Waters, 3rd edn., John Wiley \& Sons, New York, 1022 pp., 1996.

Sunda, W. G. and Kieber, D. J.: Oxidation of Humic Substances by Manganese Oxides Yields Low-Molecular-Weight Organic Substrates, Nature, 367, 62-64, 1994.

Taillefert, M., MacGregor, B. J., Gaillard, J. F., Lienemann, C. P., Perret, D., and Stahl, D. A.: Evidence for a dynamic cycle between $\mathrm{Mn}$ and $\mathrm{Co}$ in the water column of a stratified lake, Environ. Sci. Technol., 36, 468-476, 2002.

Tebo, B. M. and Emerson, S.: Effect of oxygen tension, Mn(II) concentration, and temperature on the microbially catalyzed Mn(II) oxidation rate in a marine fjord, Appl. Environ. Microbiol., 50, 1268-1273, 1985.

Tebo, B. M., Clement, B. G., and Dick, G. J.: Biotransformations of manganese, in: Manual of Environmental Microbiology, 3rd edn., edited by: Hurst, C. J., Crawford, R. L., Garland, J. L., Lipson, D. A., Mills, A. L., and Stetzenbach, L. D., ASM Press, Washington D.C., 1223-1238, 2007.

Thamdrup, B.: Bacterial manganese and iron reduction in aquatic sediments, Adv. Microb. Ecol., 16, 41-84, 2000.

Thamdrup, B. and Dalsgaard, T.: The fate of ammonium in anoxic manganese oxide-rich marine sediment, Geochim. Cosmochim. Ac., 64, 4157-4164, 2000.

Troup, B. N., Bricker, O. P., and Bray, J. T.: Oxidation Effect on Analysis of Iron in Interstitial Water of Recent Anoxic Sediments, Nature, 249, 237-239, 1974.

Tsikos, H., Beukes, N. J., Moore, J. M., and Harris, C.: Deposition, diagenesis, and secondary enrichment of metals in the Paleoproterozoic Hotazel iron Formation, Kalahari manganese field, South Africa, Econ. Geol. Bull. Soc., 98, 1449-1462, 2003.

Van Cappellen, P. and Wang, Y.: Metal cycling in surface sediments: modeling the interplay of transport and reaction, in: Metal Contaminated Sediments, edited by: Allen, H. E., Ann Arbor Press, Chelsea, MI, 21-64, 1995.

Van Cappellen, P. and Wang, Y.: Cycling of iron and manganese in surface sediments: a general theory for the coupled transport and reaction of carbon, oxygen, nitrogen, sulfur, iron, and manganese, Am. J. Sci., 296, 197-243, 1996.

Villalobos, M., Toner, B., Bargar, J., and Sposito, G.: Characterization of the manganese oxide produced by Pseudomonas putida strain MnB1, Geochim. Cosmochim. Ac., 67, 2649-2662, 2003.

Viollier, E., Inglett, P. W., Hunter, K., Roychoudhury, A. N., and Van Cappellen, P.: The ferrozine method revisited: $\mathrm{Fe}(\mathrm{II}) / \mathrm{Fe}(\mathrm{III})$ determination in natural waters, Appl. Geochem., 15, 785-790, 2000.

Yao, W. S. and Millero, F. J.: The Rate of Sulfide Oxidation by Delta-Mno2 in Seawater, Geochim. Cosmochim. Ac., 57, 33593365, 1993. 